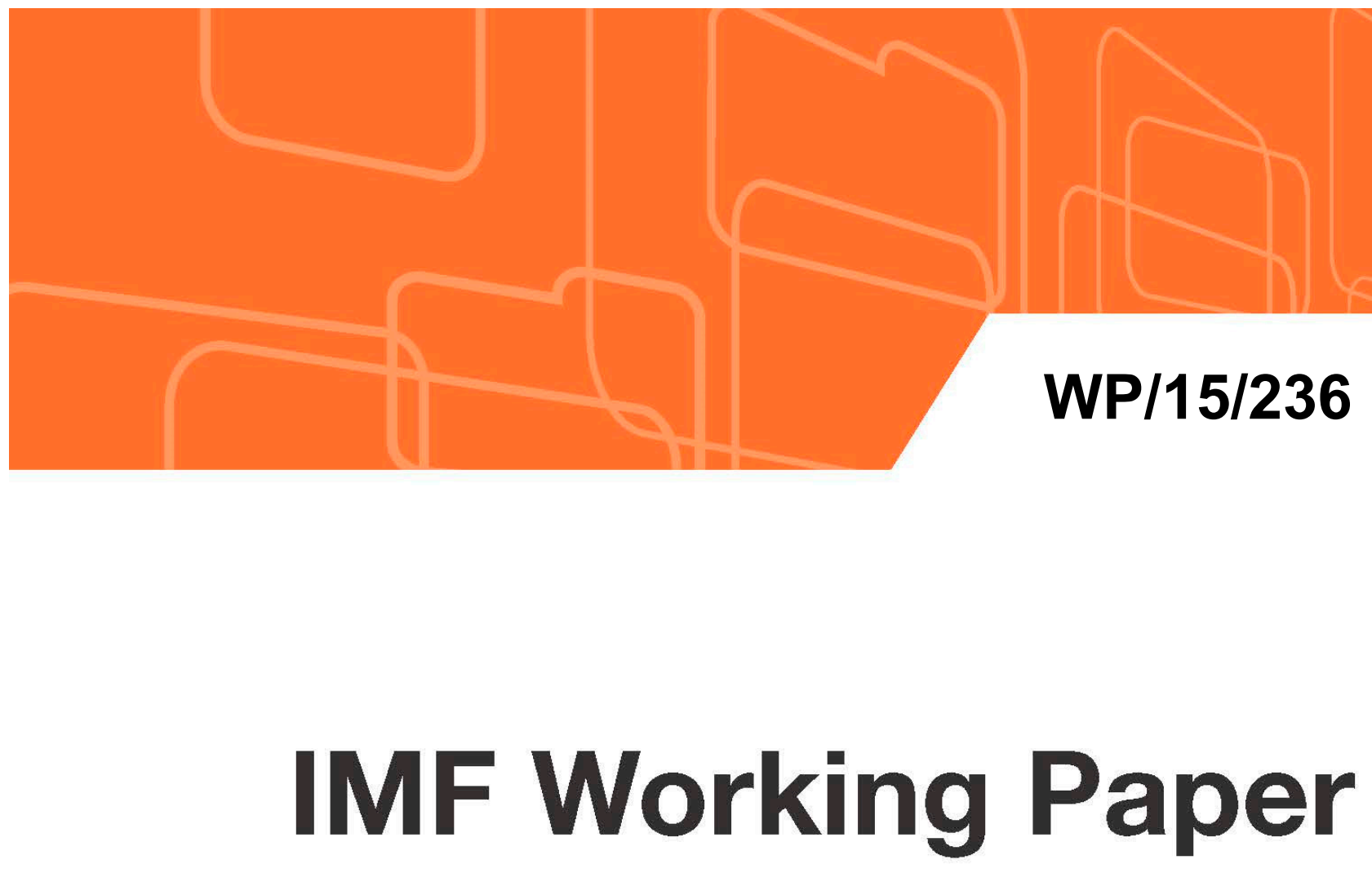

\title{
Public Investment in a Developing Country Facing Resource Depletion
}

by Adrian Alter, Matteo F. Ghilardi and Dalia S. Hakura 


\title{
IMF Working Paper
}

\author{
African Department \\ Public Investment in a Developing Country Facing Resource Depletion \\ Prepared by Adrian Alter, Matteo F. Ghilardi and Dalia S. Hakura ${ }^{1}$ \\ Authorized for distribution by Anne-Marie Gulde-Wolf
}

November 2015

\begin{abstract}
IMF Working Papers describe research in progress by the author(s) and are published to elicit comments and to encourage debate. The views expressed in IMF Working Papers are those of the author(s) and do not necessarily represent the views of the IMF, its Executive Board, IMF management, or DFID.
\end{abstract}

\begin{abstract}
This paper analyzes the tradeoffs between savings, debt and public investment in the Republic of Congo, a developing country with looming oil exhaustibility concerns. Our results highlight the risks to fiscal and capital sustainability of oil exporting countries from large scaling-up in public investment and oil price volatility in view of a projected decline in the oil revenue to GDP ratio. However, structural reforms that improve the efficiency of public investment can allow for a relatively faster buildup of sustainable public capital and sustain higher non-oil growth without adversely affecting the debt ratio or savings. Moreover, we show that even if a government pursues prudent fiscal policy that preserves resource wealth and debt sustainability in the face of exhaustible and volatile resource revenues, low public investment quality in the form of a misallocation of resources can hinder attainment of sustainable public capital and positive non-oil growth.
\end{abstract}

JEL Classification Numbers: E22, E62, F34, Q32, Q38

Keywords: Public Capital, Debt Sustainability, Investment Efficiency, Project Selection Author’s E-Mail Address: aalter@imf.org mghilardi@imf.org dhakura@imf.org

\footnotetext{
${ }^{1}$ The authors thank for comments and discussions Emre Alper, Andrew Berg, Mario de Zamaroczy, Domenico Fanizza, Anne-Marie Gulde-Wolf, Grace Bin Li, Rodolfo Maino, Cameron McLoughlin, Giovanni Melina, Susan Yang, Felipe Zanna and conference participants at the CSAE Conference 2015 held in Oxford. This paper is part of a research project on macroeconomic policy in low-income countries supported by the U.K.'s Department for International Development (DFID). All remaining errors are our own.
} 


\section{Contents}

\begin{tabular}{llr}
\hline I & Introduction & 3
\end{tabular}

\begin{tabular}{llr}
\hline II A cross-country perspective & 6
\end{tabular}

$\begin{array}{lr}\text { III The model } & 7\end{array}$

A. Households . . . . . . . . . . . . . . . . . . . . . . . . . . . . . . . . . . . . . 8

B. Firms . . . . . . . . . . . . . . . . . . . . . . 11

C. Government . . . . . . . . . . . . . . . . . . . . . . . . . . 13

D. Market Clearing . . . . . . . . . . . . . . . . . . . . . . . . . 15

\begin{tabular}{ll}
\hline IV Calibration & 15
\end{tabular}

A. Macroeconomic developments . . . . . . . . . . . . . . . . . . . . . . 16

B. Benchmark scenario: public investment profile . . . . . . . . . . . . . . . . . . . 17

C. Efficiency and absorptive capacity constraints . . . . . . . . . . . . . . . . . . . . . . 18

\begin{tabular}{|rr}
\hline V & 19 \\
\hline$A$
\end{tabular}

A. Model Simulations: Investment profiles . . . . . . . . . . . . . . . . . . . . . . . . . 20

B. Model Simulations: Project Implementation Efficiency . . . . . . . . . . . . . . . . . 23

C. Model Simulations: Oil revenue shock . . . . . . . . . . . . . . . . . . . . . . . . . 25

D. Model Simulations: Project selection . . . . . . . . . . . . . . . . . . . . . . . 27

\begin{tabular}{lr}
\hline VI Conclusions & 29
\end{tabular}

\section{List of Figures}

$1 \quad$ Oil sector relevance, capital expenditure, and resource exhaustibility (2013) 6

2 Congo: Oil production profile and price assumptions 17

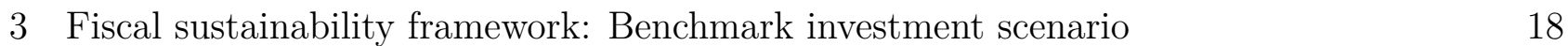

\begin{tabular}{lll}
\hline 4 & Benchmark scenario & 20
\end{tabular}

\begin{tabular}{lll}
5 & Aggressive scenario & 22 \\
\hline 6 & Constant scenario
\end{tabular}

\begin{tabular}{lll}
\hline 6 & Constant scenario & 23
\end{tabular}

\begin{tabular}{|lll}
\hline 7 & Benchmark scenario: structural reforms & 24
\end{tabular}

\begin{tabular}{lll}
\hline & Aggressive scenario - structural reforms & 25
\end{tabular}

9 Benchmark scenario: Oil Shocks (confidence intervals) 26

10 Project selection: public capital and non-oil GDP growth 28

11 Aggressive scenario: oil shocks (confidence intervals) 33

12 Constant scenario: oil shocks (confidence intervals)

\section{List of Tables}

1 A cross-country macroeconomic comparison among developing oil exporters 7

2 Structural parameters 32 


\section{Introduction}

En route to becoming emerging markets, resource-rich developing countries must address poverty and infrastructure gaps. On average, resource-rich developing countries experience poverty headcounts in excess of 55 percent, human development indicators in the bottom 50 percent, and less than 30 percent of the roads are paved (e.g., IMF 2012). Despite the abundance of natural resource revenues, these countries face absorptive capacity constraints and institutional inefficiencies to manage public investments. The efficiency of public investment depends on institutional factors, such as the capacity to implement, select, and evaluate projects. These features are strongly linked to the business climate, corruption and the availability of skilled human capital.

Natural resource wealth provides an opportunity for developing countries to accelerate economic development. At the same time, managing the natural resource wealth poses a challenge because of the exhaustible and volatile nature of the resource revenues. The theoretical literature of natural resource management proposes several public investment strategies. Some theoretical work has advocated "the bird-in-hand" approach which argues for countries that experience resource windfalls to accumulate these revenues in a Sovereign Wealth Fund (SWF) and consume only the interest from this fund. As the natural resources deplete, the government uses the SWF to smooth its investment spending (Collier and others 2010). Other studies have called for a portion of the resource windfall to be saved and the rest invested as a way to speed up economic development and build essential public infrastructure that provides an impetus for growth and reduces poverty (Sachs and Warner 1997). . $^{1}$ However, scaling up public investment in developing countries may not always enhance growth. Low public investment efficiency (a dollar of investment typically translates to 50 cents of public capital in developing countries (Pritchett 2000) and absorptive capacity constraints (from poor infrastructure, supply chain bottlenecks, and lack of qualified workers that increase the associated costs, among other things) can significantly diminish the growth benefits of public investment (Berg and others 2013 and van der Ploeg 2012). Also, in resource-rich countries, spending resource revenues domestically may trigger Dutch Disease effects, adversely affecting the competitiveness of traded good sectors and, hence, growth (e.g. Sachs and Warner 2001, van der Ploeg and Poelhekke 2010, and van der Ploeg 2011).

This paper assesses the growth and sustainability effects of different public investment paths for a small open economy that is at the peak of oil production and has a relatively short remaining oil revenue horizon. It uses a Dynamic Stochastic General Equilibrium (DSGE) model

${ }_{1}^{1}$ Collier and others $(2010)$ make the case for developing resource-rich economies to prioritize capital investment, after building up sufficient fiscal buffers to sustain external shocks. van der Ploeg (2012) claims that more weight should be given to current generations than in the permanent income hypothesis approach, in order to address the poverty gap. He argues that by managing the natural resource revenues optimally, these countries could ramp up public investment which positively impacts current wages and consumption. 
as in Melina, Yang, and Zanna (2014) which extends the models of Buffie and others (2012) and Berg and others (2013) and features a natural resource sector, multiple debt instruments, investment efficiency and absorptive capacity constraints, Dutch Disease effects, and a SWF. Taking resource revenue and public investment paths as exogenous, the macroeconomic model simulates outcomes related to growth, public debt, SWF, and the stock of capital, over a period of 17 years (i.e., 2014-2030). By incorporating public capital in the production function, this model allows for a direct impact of public investment on non-resource GDP growth. In this way, the paper allows an analysis of the tradeoffs between public investment decisions, savings and debt for countries with depleting resources.

Berg and others (2013) has previously studied the macroeconomic effects of public investment in resource rich countries in a DSGE framework. This work assumes that public investment can only be financed from resource revenues and there is no scope for debt-financed investment. As in Melina, Yang, and Zanna (2014), the present paper examines alternative investment scenarios where public investment can be financed through resource revenues and debt. Hence, the model allows an assessment of debt sustainability and the growth effects of alternative investment strategies. Also, this paper focuses on an application to a country that is at the peak of the resource windfall rather than a country that is expecting a resource windfall. In this way, the paper derives "a sustainable investing" approach that combines public investment that meets development objectives while at the same time preserving resource wealth and maintaining macroeconomic stability along the lines analyzed in Berg and others (2013) and Melina, Yang, and Zanna (2014). The paper highlights the risks to fiscal and capital sustainability of large public investment scaling up for the reference country, a gradual reduction in public investment is needed to preserve debt sustainability and to have sufficient financing to sustain public capital after the resource windfall depletes, including in the face of resource revenue volatility.

The model is applied to the Republic of Congo (Congo hereafter) but its findings are illustrative of the policy tradeoffs faced by any highly oil-dependent country that has large social and infrastructure gaps and faces absorptive and implementation capacity constraints and where resource exhaustibility is imminent. The paper analyzes the policy tradeoffs based on four sets of simulations. First, the paper undertakes simulations to analyze alternative investment paths taking oil production and revenues as exogenous. The simulations stress the importance of fiscal consolidation for Congo to preserve macroeconomic stability in the medium- to long-run when oil reserves are exhausted. The paper shows that an aggressive scaling up of investment, could lead to a fast accumulation of public capital and higher near-term non-oil growth. However, as more oil revenues are devoted to public investment less can be saved, leaving the country vulnerable to future negative oil price shocks and the oil depletion. Public investment can also be financed by borrowing from either domestic or foreign sources. A rapid scaling up of investment could, therefore, initially result in a draw-down of the saving fund in the face of declining oil revenues. Once savings hits a minimum acceptable lower bound-in this case the level of 
reserves needed to ensure the smooth operation of the pegged exchange rate arrangement-the government can choose to borrow to close the fiscal gap 2 However, there is a limit to the level of debt market participants will be willing to provide. Therefore, eventually, once the relevant threshold for public debt is reached, a downward adjustment of government spending would become inevitable. ${ }^{3}$ The model simulations assume that the country authorities draw on their resource fund before accumulating further debt. In practice, country authorities may choose to borrow and preserve their gross savings or may engage in a combination of the two. In all cases, the longer-term effect of postponing the fiscal consolidation is to run up unsustainable public debt and leave no financial assets to provide a permanent income once oil reserves are exhausted. This paper also explores the case where public investment is maintained constant for a period of time before fiscal consolidation kicks in. Naturally, this option leads to a lower build up of savings in the long run and a higher build up of debt than the baseline fiscal consolidation scenario, and increases the vulnerability of the economy to negative oil price shocks.

Second, the paper simulates the impact of changes in public investment efficiency and absorptive capacity constraints on the sustainability of public capital and non-oil growth. We initially assume a public investment efficiency of 0.5 consistent with findings for developing countries that are typically characterized by a difficult business climate, weak institutions or poor rule of law, and that efficiency declines once public investment exceeds a given threshold. The simulations in this section highlight how structural reforms that improve efficiency can contribute to deliver a sustainable higher level of public capital and non-oil output growth without requiring additional public investment spending.

Third, the paper examines how volatility of commodity prices affects the macroeconomic outlook, in particular the amount of public debt and savings. Simulations that account for the historical volatility of oil prices are used to derive the confidence bands around the path for the resource revenue. The simulations demonstrate how the framework can inform on the public investment plans in the face of volatile oil revenues: specifically, the paper's findings highlight the downside risk and the upside potential stemming from changes in commodity prices.

Finally, we analyze the impact of the project selection process on the macroeconomic outlook and sustainable public capital stock. Unlike the second section which focuses on structural reforms that improve investment efficiency - the amount of capital produced per dollar invested - and that can increase the public capital stock, the focus of the simulations in this section are on the economic return of investments over the long term, i.e. output per unit of capital. This section introduces two types of projects in which the government can investlow and high productivity projects. Our analysis underscores that inadequate project selection processes or a misallocation of resources to lower-yield projects (including from weak gover-

\footnotetext{
${ }^{2}$ Congo is a member of the Central African Economic and Monetary Community (CEMAC) which pegs the CFA franc to the euro.

${ }^{3}$ Non-oil taxation is assumed to be unchanged. Studying the implications of relying more on non-oil revenues is outside the scope of this paper.
} 
nance and institutions) can obviate a sustainable public capital and positive non-oil growth outcome even when public investment follows a path that preserves resource wealth and debt sustainability.

The rest of the paper is organized as follows: Section II gives a cross-country perspective on the challenges facing developing country oil exporters; Section III describes the model; Section IV describes the model calibration to the case of Congo; Section V presents the results of the four sets of model simulations; and section VI summarizes the findings and discusses the policy implications.

\section{A cross-country perspective}

In this section we present a cross-country comparison across developing oil exporters that are highly dependent on oil. While oil revenues can help to accelerate economic development, oil production has a horizon of less than 20 years in several developing countries (Figure 1) and government revenues from oil are expected to decline over the medium term. The projected decline in oil revenue poses challenges to designing sustainable public investment paths that can be properly financed and that allow a buildup of savings to support government spending in the post-oil era. Figure 1 highlights that this challenge is particularly relevant for the African exporters such as Congo, Equatorial Guinea, and Gabon which have relatively shorter horizons of remaining hydrocarbon production and relatively larger capital expenditure to non-oil GDP ratios than their counterparts in the Middle East and Asia.

Figure 1: Oil sector relevance, capital expenditure, and resource exhaustibility (2013)
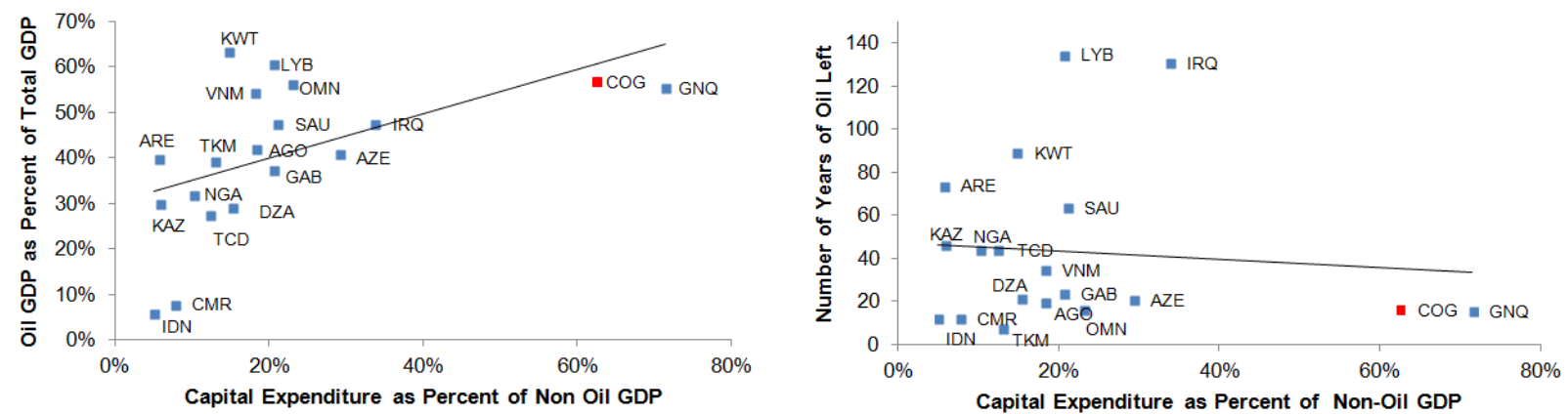

Sources: WEO database - April 2014; BP Statistical Review of World Energy - June 2014; and authors' calculations.

Note: Three-letter country codes correspond to the following countries: AGO - Angola, ARE - United Arab Emirates, AZE - Azerbaijan, CMR - Cameroon, COG - Congo, DZA - Algeria, GAB - Gabon, GNQ Equatorial Guinea, KAZ - Kazakhstan, KWT - Kuwait, LYB - Libya, IDN - India, IRQ - Iraq, SAU - Saudi Arabia, NGA - Nigeria, OMN - Oman, TCD - Chad, TKM - Turkmenistan. 
Table 1 compares developing oil exporters' resource GDP to total GDP ratios in 2013 and projections for 2019, and the 2013 values for capital expenditure to GDP ratios, government debt to GDP ratios, overall revenue to GDP ratios, non-oil primary balance to non-oil GDP ratios, and the remaining number of years of oil production. The size of the non-oil primary deficit is a proxy for the extent of fiscal adjustment that would be needed to attain a primary deficit that can be sustained once the oil resources deplete. Equatorial Guinea, Angola, and Congo stand out among the developing countries as having large non-oil primary deficits despite relatively limited horizons of oil production.

Table 1: A cross-country macroeconomic comparison among developing oil exporters

\begin{tabular}{|c|c|c|c|c|c|c|c|c|}
\hline & & \multicolumn{2}{|c|}{$\begin{array}{c}\text { Oil GDP/ Total } \\
\text { GDP }\end{array}$} & \multirow[t]{2}{*}{$\begin{array}{c}\text { Capital } \\
\text { Expenditure/ } \\
\text { Total GDP }\end{array}$} & \multirow[t]{2}{*}{$\begin{array}{c}\text { Government } \\
\text { Debt/ } \\
\text { Total GDP }\end{array}$} & \multirow{2}{*}{$\begin{array}{c}\text { Oil } \\
\text { Revenues/ } \\
\text { Total GDP } \\
2013\end{array}$} & \multirow[t]{2}{*}{$\begin{array}{c}\text { Non-oil } \\
\text { Primary } \\
\text { Balance/ Non- } \\
\text { oil GDP } \\
\end{array}$} & \multirow[t]{2}{*}{$\begin{array}{c}\text { Oil } \\
\text { Production }\end{array}$} \\
\hline & & 2013 & $\begin{array}{l}2019 \\
\text { proj. }\end{array}$ & & & & & \\
\hline & & & & & (in percent) & & & (years left) \\
\hline \multirow{5}{*}{ CEMAC } & Cameroon & 7.2 & 6.4 & 7.0 & 19.0 & 4.8 & -9.1 & 8 \\
\hline & Chad & 27.1 & 27.7 & 9.7 & 31.0 & 11.8 & -17.6 & 44 \\
\hline & Equatorial Guinea & 55.3 & 31.9 & 31.9 & 9.0 & 30.1 & -83.7 & 15 \\
\hline & Gabon & 37.1 & 21.8 & 11.0 & 18.8 & 15.8 & -17.4 & 23 \\
\hline & Republic of Congo & 58.0 & 47.0 & 24.2 & 38.2 & 34.5 & -61.1 & 16 \\
\hline \multirow{2}{*}{$\begin{array}{c}\text { Rest of } \\
\text { SSA }\end{array}$} & Angola & 40.6 & 25.5 & 12.0 & 34.6 & 30.0 & -49.7 & 19 \\
\hline & Nigeria & 12.7 & 8.2 & 3.8 & 10.4 & 7.1 & -8.4 & 44 \\
\hline \multirow{4}{*}{$\begin{array}{l}\text { Rest of } \\
\text { the } \\
\text { World }\end{array}$} & Azerbaijan & 41.0 & 32.3 & 16.6 & 13.8 & 27.7 & -45.6 & 21 \\
\hline & Trinidad and Tobago & 45.9 & 40.9 & 7.3 & 30.3 & 15.7 & -30.5 & 19 \\
\hline & Turkmenistan & 39.1 & 23.7 & 7.6 & 20.5 & 8.9 & -12.3 & 7 \\
\hline & Vietnam & 8.4 & 5.8 & 7.2 & 51.6 & 3.3 & -8.1 & 34 \\
\hline & Average & 33.8 & 24.7 & 12.6 & 25.2 & 17.3 & -31.2 & 23 \\
\hline
\end{tabular}

Sources: WEO database - April 2014; BP Statistical Review of World Energy - June 2014; and authors' calculations.

Note: CEMAC refers to Central African Economic and Monetary Community; SSA refers to sub-Saharan Africa.

\section{The model}

The paper uses a medium scale open economy DSGE model along the lines of Buffie and others (2012) and Berg and others (2013) with a sovereign wealth fund as introduced in Melina, Yang, and Zanna (2014) to analyze the feasibility of different public investment plans. The model is designed to analyze the nexus of natural resource revenue management, public investment, and public debt.

The model follows Melina, Yang, and Zanna (2014) closely. In particular, the economy constitutes of three agents: (i) households, (ii) firms and (iii) government. To capture the features of low income countries households are divided into optimizing and non-optimizing 
(hand-to-mouth consumers). The critical difference between these two is that the former have access to financial markets and can smooth consumption. The latter consume all of their disposable income each period. There are assumed to be three types of firms: (i) (non-resource) traded goods producers; (ii) non traded good producers; and (iii) natural resource producers. Government provides investment, which is productive, and consumption. Total government spending is financed with taxes, debt, and revenues from natural resource production, as well as savings in the sovereign wealth fund. The government has access to different types of debt (e.g., external and domestic financing).

\section{A. Households}

The economy features two types of households: optimizing and non optimizing (OPT) or hand-to-mouth $(H T M)$. The former have access to financial markets and can smooth their consumption over time. The latter do not have access to financial markets and they consume all their income within the period. Both households have identical preferences which are described by the following utility function:

$$
U\left(c_{t}^{i}, L_{t}^{i}\right)=\frac{1}{1-\sigma}\left(c_{t}^{i}\right)^{1-\sigma}-\frac{\kappa}{1+\psi}\left(L_{t}^{i}\right)^{1+\psi}
$$

where $c_{t}^{i}$ is consumption and $L_{t}^{i}$ is labor. The parameter $\sigma$ represents the inverse of the intertemporal elasticity of substitution, $\psi$ is the inverse of the intertemporal elasticity of substitution of the labor supply and $\kappa$ is the disutility weight of labor. The subscript $i$ indicates the type of household i.e. $i=O P T, H T M$. Both households consume a basket of traded $c_{T, t}$ and non traded goods $c_{N, t}$ according to a constant elasticity of substitution aggregator a la' Stiglitz-Dixit:

$$
c_{t}^{i}=\left[\varphi^{\frac{1}{\chi}}\left(c_{N, t}^{i}\right)^{\frac{\chi-1}{\chi}}+(1-\varphi)^{\frac{1}{\chi}}\left(c_{T, t}^{i}\right)^{\frac{\chi-1}{\chi}}\right]^{\frac{\chi}{\chi-1}}
$$

where $\varphi$ indicates the non traded goods bias and $\chi>0$ is the intratemporal elasticity of substitution. The price of consumption is normalized to 1 . This implies the following traded and non-traded price aggregator:

$$
1=\left[\varphi\left(p_{N, t}\right)^{\chi-1}+(1-\varphi)\left(s_{t}\right)^{\chi-1}\right]^{\frac{1}{\chi-1}}
$$

where $p_{N, t}$ is the price of non traded goods and $s_{t}$ represents the relative price of traded goods to the consumption basket. In our economy, given that the law of one price holds for traded goods, $s_{t}$ corresponds to the real exchange rate, defined as the price of one unit of foreign consumption basket in units of the domestic basket. Minimization of total consumption expenditures subject 
to the consumption basked yields the following demand functions for each good:

$$
\begin{gathered}
c_{N, t}^{i}=\varphi p_{N, t}^{-\chi} c_{t}^{i} \\
c_{T, t}^{i}=(1-\varphi) s_{t}^{-\chi} c_{t}^{i}
\end{gathered}
$$

Each household provides labor services to the traded and non-traded sector. Therefore, as for consumption, total labor is described by a constant elasticity of substitution aggregator:

$$
L_{t}^{i}=\left[\delta^{-\frac{1}{\rho}}\left(L_{N, t}^{i}\right)^{\frac{1+\rho}{\rho}}+(1-\delta)^{-\frac{1}{\rho}}\left(L_{T, t}^{i}\right)^{\frac{1+\rho}{\rho}}\right]^{\frac{\rho}{1+\rho}}
$$

where $\delta$ is the share of labor in the non traded sector and $\rho$ represents the intratemporal elasticity of substitution between the amount of labor supplied to the two sectors. The relative wages $w_{t}$ aggregator takes the following form:

$$
w_{t}=\left[\delta w_{N, t}^{1+\rho}+(1-\delta) w_{T, t}^{1+\rho}\right]^{\frac{1}{1+\rho}}
$$

where $w_{N, t}$ is the real wage paid in the non traded sector and $w_{T, t}$ is the real wage paid in the traded sector. Maximization of total labor income subject to aggregate labor yields the following labor supply schedule for each sector:

$$
\begin{gathered}
L_{N, t}^{i}=\delta\left(\frac{w_{N, t}}{w_{t}}\right)^{\rho} L_{t}^{i} \\
L_{T, t}^{i}=(1-\delta)\left(\frac{w_{T, t}}{w_{t}}\right)^{\rho} L_{t}^{i}
\end{gathered}
$$

Total consumption and labor are respectively the sum of consumption and labor in each household:

$$
\begin{gathered}
c_{t}=\omega c_{t}^{O P T}+(1-\omega) c_{t}^{H T M} \\
L_{t}=\omega L_{t}^{O P T}+(1-\omega) L_{t}^{H T M}
\end{gathered}
$$

\section{A.1. Optimizing Households}

Optimizing households maximize the discounted sum of their lifetime utility functions:

$$
E_{0} \sum_{t=0}^{\infty} \beta^{t} U\left(c_{t}^{O P T}, L_{t}^{O P T}\right)
$$


subject to the following budget constraint:

$$
\begin{aligned}
\left(1+\tau^{c}\right) c_{t}^{O P T}+b_{t}^{O P T}-s_{t} b_{t}^{O P T *}+i_{t}^{T}+i_{t}^{N T}= & \left(1-\tau^{L}\right) w_{t} L_{t}^{O P T}+ \\
& +\left(1-\tau^{K}\right)\left(r_{K, t}^{T} k_{t-1}^{T}+r_{K, t}^{N T} k_{t-1}^{N T}\right)+ \\
& +R_{t-1} b_{t-1}^{O P T}-R_{t-1}^{*} s_{t} b_{t-1}^{O P T *}-\Theta_{t}^{O P T *}+ \\
& +s_{t} r m_{t}+z_{t}+\mu k_{G, t-1}+\Omega_{T, t}+\Omega_{N T, t}
\end{aligned}
$$

where $\beta=(1+\varrho)^{-1}$ is the discount factor, $\varrho$ is the rate of time preference and $\tau^{c}$ and $\tau^{L}$ are tax rates on consumption and labor respectively. The term $r m_{t}$ denotes remittances from abroad, $z_{t}$ are transfers from government, $\mu$ are use fees paid for the use of public capital $k_{G, t-1}$ and $\Omega_{T, t}, \Omega_{N T, t}$ are profits from the firms in the traded and non-traded sector respectively. We assume that optimizing households hold physical capital $k_{t}$ used for production in the traded and non-traded sector:

$$
k_{t}^{j}=\left(1-\delta^{j}\right) k_{t-1}^{j}+\left[1-\frac{\kappa^{j}}{2}\left(\frac{i_{t}^{j}}{i_{t-1}^{j}}-1\right)^{2}\right] i_{t}^{j}
$$

where the subscript $j=T, N T$ indicated the traded and non-traded sector respectively. The parameter $\delta$ indicates the depreciation rate, $\kappa$ is the investment adjustment cost.

Optimizing households have access to financial markets in the form of domestic bonds $b_{t}^{O P T}$ and international bonds $b_{t}^{O P T *}$. The term $\Theta_{t}^{O P T *}=\frac{\eta}{2}\left(b_{t}^{O P T *}-b^{O P T *}\right)^{2}$ represents portfolio adjustment costs associated with the purchase of foreign liabilities. The term $\eta$ controls the capital account openness and $b^{O P T *}$ denotes the steady state value of private foreign debt. Finally, we assume that the return on debt contracted externally pays a premium over the interest debt on commercial debt $R_{d c, t}$ contracted by the government:

$$
R_{t}^{*}=R_{d c, t}+u
$$

Let $\lambda_{t}$ be the Lagrange multiplier associated with the budget constraint and $q_{t}^{j}$ the lagrange multiplier associated with the law of motion of private capital in each sector. Then, the maximization problem delivers the following first order conditions:

$$
\begin{gathered}
\lambda_{t}\left(1+\tau_{t}^{c}\right)=\left(c_{t}^{O P T}\right)^{-\sigma} \\
\kappa\left(L_{t}\right)^{\psi}=\lambda_{t}\left(1-\tau_{t}^{L}\right) w_{t} \\
\lambda_{t}=\beta E_{t}\left(\lambda_{t+1} R_{t}\right)
\end{gathered}
$$




$$
\begin{gathered}
\lambda_{t}=\beta E_{t}\left[\frac{\lambda_{t+1} s_{t+1} R_{t}^{*}}{s_{t}-\eta\left(b_{t}^{O P T *}-b^{O P T *}\right)}\right] \\
q_{t}^{j}=E_{t}\left[\beta \frac{\lambda_{t+1}}{\lambda_{t}}\left((1-\delta) q_{t+1}^{j}+\left(1-\tau^{K}\right) r_{K, t}^{j}\right)\right] \\
\frac{1}{q_{t}^{j}}=\left[1-\frac{\kappa^{j}}{2}\left(\frac{i_{t}^{j}}{i_{t-1}^{j}}-1\right)^{2}-\kappa^{j}\left(\frac{i_{t}^{j}}{i_{t-1}^{j}}-1\right) \frac{i_{t}^{j}}{i_{t-1}^{j}}\right]+ \\
+\left[\beta \frac{\lambda_{t+1}}{\lambda_{t}} \kappa^{j} \frac{q_{t+1}^{j}}{q_{t}^{j}}\left(\frac{i_{t}^{j}}{i_{t-1}^{j}}-1\right)\left(\frac{i_{t+1}^{j}}{i_{t}^{j}}\right)^{2}\right]
\end{gathered}
$$

\section{A.2. Non-Optimizing Households}

Non optimizing households maximize the current period utility function:

$$
U\left(c_{t}^{H T M}, L_{t}^{H T M}\right)
$$

subject to the following budget constraint:

$$
\left(1+\tau_{t}^{c}\right) c_{t}^{H T M}=\left(1-\tau_{t}^{L}\right) w_{t} L_{t}^{H T M}+s_{t} r m_{t}+z_{t}+\mu k_{G, t-1}
$$

Static maximization leads to the following labor supply function:

$$
L_{t}=\left[\frac{1}{\kappa} \frac{1-\tau_{t}^{L}}{1+\tau_{t}^{c}}\left(c_{t}\right)^{-\sigma} w_{t}\right]^{\frac{1}{\psi}}
$$

\section{B. Firms}

The economy features three production sectors: (i) traded goods, (ii) non-traded goods and (iii) natural resource production. We refer to the first two as the goods production sectors.

\section{B.1. Goods Production Sector}

Traded and non-traded goods produce goods according to a Cobb-Douglas production function:

$$
y_{t}^{j}=z^{j}\left(k_{t-1}^{j}\right)^{1-\alpha^{j}}\left(L_{t}^{j}\right)^{\alpha^{j}}\left(k_{t-1}^{G}\right)^{\alpha^{G}}
$$


where the subscript $j=T, N T$ indicated the traded and non-traded sectors respectively. The parameter $\alpha^{j}$ indicate the labor share and $\alpha^{G}$ is the elasticity of output with respect to private capital. The term $z^{j}$ represents total factor productivity. We assume that the traded sector is subject to learning-by-doing externalities:

$$
\frac{z_{t}^{T}}{z^{T}}=\left(\frac{z_{t-1}^{T}}{z^{T}}\right)^{\rho^{z}}\left(\frac{y_{t-1}^{T}}{y^{T}}\right)^{\rho^{y}}
$$

where $\rho^{z}, \rho^{y} \in[0,1]$ control the severity of Dutch disease as in Matsuyama (1992) and Krugman (1987).

Profit maximization delivers the following first order conditions for the traded goods producers:

$$
\begin{gathered}
r_{K, t}^{T}=\left(1-\alpha^{T}\right) s_{t} \frac{y_{t}^{T}}{k_{t-1}^{T}} \\
w_{t}^{T}=\alpha^{T} s_{t} \frac{y_{t}^{T}}{L_{t}^{T}}
\end{gathered}
$$

and the following for the non-traded goods producers:

$$
\begin{gathered}
r_{K, t}^{N T}=\left(1-\alpha^{N T}\right) p_{t}^{N T} \frac{y_{t}^{N T}}{k_{t-1}^{N T}} \\
w_{t}^{N T}=\alpha^{N T} p_{t}^{N T} \frac{y_{t}^{N T}}{L_{t}^{N T}}
\end{gathered}
$$

\section{B.2. Natural Resource Sector}

Natural resource production $y_{t}^{O}$ is assumed to follow an exogenous process:

$$
\frac{y_{t}^{O}}{y^{O}}=\left(\frac{y_{t-1}^{O}}{y^{O}}\right)^{\rho^{y^{O}}} \exp \left(\varepsilon_{t}^{y^{O}}\right)
$$

where $\rho^{y^{O}}$ is an autoregressive coefficient and $\varepsilon_{t}^{y^{O}}$ is the resource production shock. We assume that resource production is small relative to world production, and, therefore, that the international price of the natural resource is given and evolves as:

$$
\frac{p_{t}^{O}}{p^{O}}=\left(\frac{p_{t-1}^{O}}{p^{O}}\right)^{\rho^{p^{O}}} \exp \left(\varepsilon_{t}^{p^{O}}\right)
$$

where $\rho^{p^{O}}$ is an autoregressive coefficient and $\varepsilon_{t}^{p^{O}}$ is the resource price shock. Resource GDP 
in units of the consumption basket can be expressed as:

$$
y_{t}^{O}=s_{t} p_{t}^{O} y_{t}^{O}
$$

The natural resource producer pays a tax on the output produced, therefore her profits are equal to:

$$
\Omega_{t}^{O}=\left(1-\tau_{t}^{O}\right) y_{t}^{O}
$$

\section{Government}

The government collects revenues from consumption, labor and capital. It levies user fees from existing infrastructures and benefits from windfall revenues. The revenues are spent on infrastructure needs, government consumption, debt services and transfers. When revenues fall short, the deficit is covered by borrowing. Formally the budget constraint can be written as:

$$
\begin{aligned}
& \tau^{c} c_{t}+\tau^{L} w_{t} L_{t}+\tau^{K}\left(r_{K, t}^{T} k_{t-1}^{T}+r_{K, t}^{N T} k_{t-1}^{N T}\right)+s_{t} g r_{t}^{*}+ \\
& +\mu_{t} k_{G, t-1}+t_{t}^{O}+b_{t}+s_{t} d_{t}+s_{t} d_{c, t}+s_{t} r^{R F} f_{t-1}^{*} \\
= & p_{t}^{G} g_{t}+z_{t}+r_{t-1} b_{t-1}+s_{t} r_{d, t} d_{t-1}+s_{t} r_{d c, t} d c_{t-1}+s_{t} f_{t}^{*}
\end{aligned}
$$

The left hand side corresponds to the period revenues and the right hand side to the period expenses. On the revenue side, the term $g r_{t}^{*}$ corresponds to international grants, $\mu k_{G, t-1}$ are user fees which are computed as a fraction $f$ of recurrent costs: $\mu_{t}=f p_{t}^{G} \delta^{G}$. The term $t_{t}^{O}$ corresponds to natural resource royalties and corresponds to $t_{t}^{O}=\tau_{t}^{O} s_{t} p_{t}^{O} y_{t}^{O}$. The government can issue three types of debt: domestic debt $b_{t}$, external concessional debt $d_{t}$ and external commercial debt $d c_{t}$. The interest rate paid on the domestic debt corresponds to $r_{t}$, to concessional debt $r_{d, t}$. We assume that the interest rate paid on commercial debt $r_{d c, t}$ is contracted at a premium over the risk free world interest rate $r_{f, t}$ :

$$
r_{d c, t}=r_{f, t}+\nu_{d c} e^{\eta_{g}\left(\frac{d_{t}+d_{c, t}}{y_{t}}-\frac{d+d_{c}}{y}\right)}
$$

where $\nu_{d c}$ and $\eta_{g}$ are structural parameters.

We assume that the government can consume and invest in the economy. This implies $g_{t}=g_{t}^{C}+g_{t}^{I}$, where $g_{t}^{C}$ is government consumption and $g_{t}^{I}$ represents government investment. The price index of government consumption $p_{t}^{G}$ in terms of units of the domestic consumption composite can be expressed as:

$$
p_{t}^{G}=\left[\nu_{t} p_{N}^{1-\chi}+\left(1-\nu_{t}\right) s_{t}^{1-\chi}\right]^{\frac{1}{1-\chi}}
$$


where $\nu_{t}$ is equal to:

$$
\nu_{t}=\frac{\left(p^{G} g\right) \nu+\left(p_{t}^{G} g_{t}-p^{G} g\right) \nu_{g}}{p_{t}^{G} g_{t}}
$$

Public investment is productive and public capital evolves according to a standard law of motion:

$$
k_{t}^{G}=\left(1-\delta^{G}\right) k_{t-1}^{G}+\tilde{g}_{t}^{I}
$$

The term $\tilde{g}_{t}^{I}$ represents effective public investment since public investment features inefficiency and absorptive capacity constraints. This implies that one dollar of public investment spending does not translate into one dollar of effectively produced capital. To reflect this, effective investment is given by

$$
\widetilde{g}_{t}^{I}=\left\{\begin{array}{ccc}
\bar{\epsilon} g_{t}^{I} & \text { if } & \bar{\gamma} \leq \bar{\gamma}^{G I} \\
\bar{\epsilon}\left(1+\bar{\gamma}^{G I}\right) \bar{g}^{I}+\epsilon\left(\bar{\gamma}_{t}^{G I}\right)\left[1+\bar{\gamma}_{t}^{G I}-\bar{\gamma}^{G I}\right] \bar{g}^{I} & \text { if } & \bar{\gamma}_{t}^{G I}>\bar{\gamma}^{G I}
\end{array}\right.
$$

where $\bar{\gamma}_{t}^{G I} \equiv \frac{g_{t}^{I}}{\bar{g}^{I}}-1$ is the percent deviation of public investment from its initial steady state and $\bar{\epsilon} \in[0,1]$ represents steady-state efficiency and $\epsilon\left(\bar{\gamma}_{t}^{G I}\right) \in(0,1]$ governs the efficiency of the portion of public investment exceeding threshold $\bar{\gamma}^{G I}$, in terms of percent deviation from the initial steady state. In particular, we assume that $\epsilon\left(g_{t}^{I}\right)$ takes the following specification:

$$
\epsilon\left(g_{t}^{I}\right)=\exp \left[-\varsigma_{\epsilon}\left(\gamma_{t}^{G I}-\bar{\gamma}^{G I}\right)\right] \bar{\epsilon}
$$

In other words, if government investment expenditure deviates from the initial steady state more than $\bar{\gamma}^{G I}$, the efficiency of the additional investment decreases to an extent proportional to the size of the deviation. This mechanism captures absorptive capacity constraints in developing countries. The severity of absorptive capacity constraints is measured by parameter $\varsigma_{\epsilon} \in[0, \infty)$.

The term $f_{t}^{*}$ in the budget constraint represents the stock of financial assets held in the resource wealth fund. We assume that in each period it earns interest income $s_{t}\left(r_{r f}-1\right) f_{t-1}^{*}$. The resource fund evolves according to the following process:

$$
f_{t}^{*}-f^{*}=\max \left\{f_{\text {floor }}-f^{*},\left(f_{t-1}^{*}-f^{*}\right)+\frac{f_{\text {in }, t}}{s_{t}}-\frac{f_{\text {out }, t}}{s_{t}}\right\}
$$

where $f^{*}$ is the initial steady-state value of the fund; $f_{\text {floor }} \geq 0$ is a lower bound for the SWF that the government chooses to maintain; $f_{\text {in,t }}$ represents the total fiscal inflow and $f_{\text {out }, t}$ represents the total fiscal outflow and are defined as:

$f_{i n, t}=\tau^{c} c_{t}+\tau^{L} w_{t} L_{t}+\tau^{K}\left(r_{K, t}^{T} k_{t-1}^{T}+r_{K, t}^{N T} k_{t-1}^{N T}\right)+s_{t} g r_{t}^{*}+\mu_{t} k_{G, t-1}+t_{t}^{O}+s_{t} \Delta d_{t}+s_{t}\left(r^{R F}-1\right) f_{t-1}^{*}$ 


$$
f_{\text {out }, t}=p_{t}^{G} g_{t}+z_{t}+\left(r_{t-1}-1\right) b_{t-1}+s_{t}\left(r_{d, t}-1\right) d_{t-1}+s_{t}\left(r_{d c, t}-1\right) d c_{t-1}
$$

Every period, if the fiscal inflow exceeds the fiscal outflow, more resources are saved in the resource fund. If the sovereign wealth fund is above $f_{\text {floor }}$ any fiscal outflow that exceeds the fiscal inflow is absorbed by a withdrawal from the fund. Whenever the lower bound constraint binds, fiscal policy reacts to cover the gap via borrowing. ${ }^{4}$

\section{Market Clearing}

To close the model we impose the market clearing condition and the balance of payment conditions. The market clearing condition for non traded goods is defined as:

$$
y_{N, t}=\varphi p_{N, t}^{-\chi}\left(c_{t}+i_{N, t}+i_{T, t}\right)+\nu_{t}\left(\frac{p_{N, t}}{p_{t}^{G}}\right)^{-\chi} g_{t}
$$

Finally, the aggregate budget constraint of consumers and government produce the account identity that growth in the country's net foreign debt equals the difference between national spending and national income:

$$
\begin{aligned}
& s_{t}\left[g r_{t}^{*}-\left(f_{t}^{*}-f_{t-1}^{*}\right)+\left(d_{t}-d_{t-1}\right)+\left(d_{c, t}-d_{c, t-1}\right)+\left(b_{t}^{*}-b_{t-1}^{*}\right)\right] \\
= & c_{t}+i_{N, t}+i_{T, t}+p_{t}^{G} g_{t}+\Theta_{t}^{O P T *}+s_{t} r m_{t}^{*}+\left(R_{d, t}-1\right) s_{t} d_{t-1}+ \\
& +\left(R_{d c, t}-1\right) s_{t} d_{c, t-1}+\left(R_{t-1}^{*}-1\right) s_{t} b_{t-1}^{*}-\left(R_{t-1}^{R F}-1\right) s_{t} f_{t-1}^{*}
\end{aligned}
$$

The right hand side corresponds to the balance of payment and the left hand side is the current account deficit.

\section{Calibration}

The model is calibrated to the characteristics of Congo and it is calibrated with annual data. The initial steady state is based on macroeconomic developments at the end of 2013 (IMF(2014a) and our projections run over the period 2014-2030, close to the complete depletion of the natural resource windfall. Private investment in terms of GDP is calibrated at 0.093, the export share in terms of GDP is set at 0.43 and the import share at 0.14 . The share of oil GDP to total GDP is set at 88.4 percent. On the fiscal side, the ratio of government consumption to

\footnotetext{
${ }^{4}$ The paper makes the simplifying assumption that the gap is covered by new borrowing. However, the government can also cover the gap by increasing taxes (on consumption and factor incomes) or cuts in government non-capital expenditures (government consumption and transfers).
} 
GDP is set at 14 percent and the ratio of government investment to GDP is set at 6 percent. The size of the sovereign wealth fund at the end of 2013 is 66.5 percent of GDP. The initial ratio of public concessional debt is set at 18.9 percent and public domestic and commercial debt in terms of GDP are set at 1 percent. For the remaining parameters we follow the standard values in the literature (see Buffie and others (2012), Berg and others (2013), Melina, Yang, and Zanna (2014) and Ghilardi and Sola (2015)). Table 2 in the Appendix provides a complete list of the parameters with the relative calibration used in the model.

\section{A. Macroeconomic developments}

Economic developments in Congo have been closely tied to developments in the oil sector. Currently, oil production accounts for 58 percent of GDP, oil exports account for 78 percent of exports, and the government's revenues from oil represent 74 percent of total fiscal revenues. The government is drawing on its oil revenues to implement an ambitious investment plan to develop the economy and address social and infrastructure gaps. As depicted in Figure 2. Congo's oil output is projected to peak in 2017 at around 118 million barrels, with the coming on-stream of the Moho Nord oil field when oil production is expected to surpass its previous peak level of 115 million barrels in 2010. However, unless there is a new discovery, oil production is projected to decline steadily over the next 15 years. As a consequence, oil revenues are expected to decline from around 33 percent of GDP in 2013 to less than 4 percent of GDP in 2030. Oil prices are calibrated to the IMF's World Economic Outlook (WEO) price forecast $(\mathrm{IMF}(2014 \mathrm{~b}))$. The projected decline in oil revenues poses challenges in terms of designing sustainable public investment paths that can be properly financed and which allow a build up of savings that could support government spending in the post-oil era. 
Figure 2: Congo: Oil production profile and price assumptions

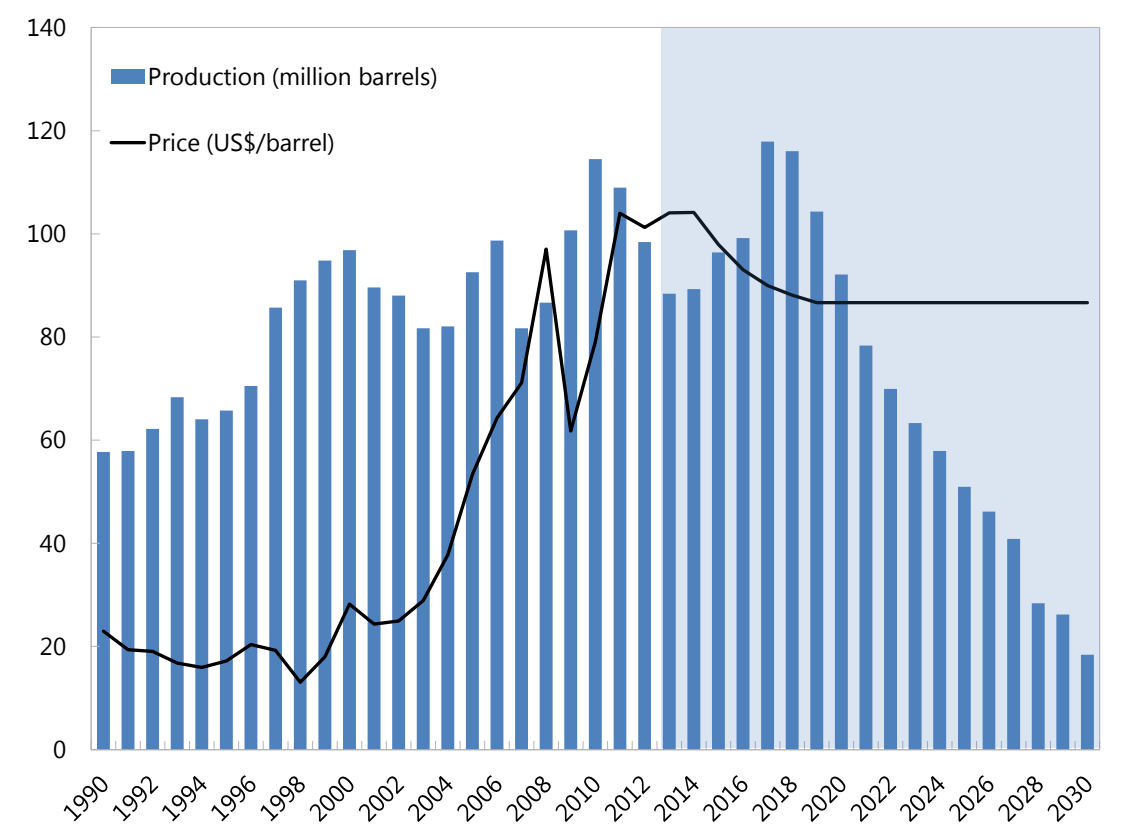

Sources: WEO projections (IMF 2014b; 2014a); and authors' calculations.

\section{B. Benchmark scenario: public investment profile}

In order to calibrate the benchmark path of public investment, a standard fiscal sustainability framework for resource-rich countries is used. The objective of this long-term framework is to steadily reduce the non-oil primary deficit. The rationale behind this framework is to delink fiscal policy from the volatility of oil revenues and to avoid the need to adjust spending abruptly when oil revenues are exhausted, which would negatively impact economic activity. At the end of 2013, the non-oil primary deficit stood at around 26 percent of GDP. At the same time, capital expenditures represented 24 percent of GDP while total expenditures totaled 38 percent of GDP. As oil revenues deplete, capital expenditures are projected to follow a similar path, stabilizing at around 13 to 14 percent of GDP in the long-run. Non-oil GDP growth is expected to average around 5 percent per year, allowing non-oil revenues to increase from 12 percent of GDP in 2013 to around 29 percent of GDP at the end of 2030. The consolidated effect of these developments delivers a non-oil primary balance close to zero by 2030 which can be sustained.

The benchmark profile takes into account also the ambitious investment program of the Congo. The National Development Plan ("Plan National de Développement") for 2012-2016 outlines several important infrastructure projects (e.g., the Pointe Noire - Brazzaville road, modernizing the Djiri power plant and the power grid). The scale of this program is a consequence of several positive developments. First, oil revenues have rebounded after the global 
financial crisis to around 33 percent of GDP in 2013 (see Figure 3). Second, Congo benefited from HIPC and MDRI debt relief, which reduced the stock of external debt by $\$ 1.9$ billion, to about 20 percent of GDP in 2010. At the end of 2013, the stock of external public debt represented 32 percent of GDP: $5^{5}$ Most of these obligations are concessional bilateral loans from China. In addition to allowing the government to boost spending, the large oil revenues from consecutive years of high international oil prices have allowed the government to set aside substantial fiscal savings and accumulate foreign exchange reserves. Following IMF(2014a), the initial value of the SWF is taken to be 66.5 percent at end-2013 primarily reflecting gross official reserves. In order to maintain an adequate level of reserve coverage and fiscal buffers, the floor for the SWF is set at 40 percent of GDP.

Figure 3: Fiscal sustainability framework: Benchmark investment scenario

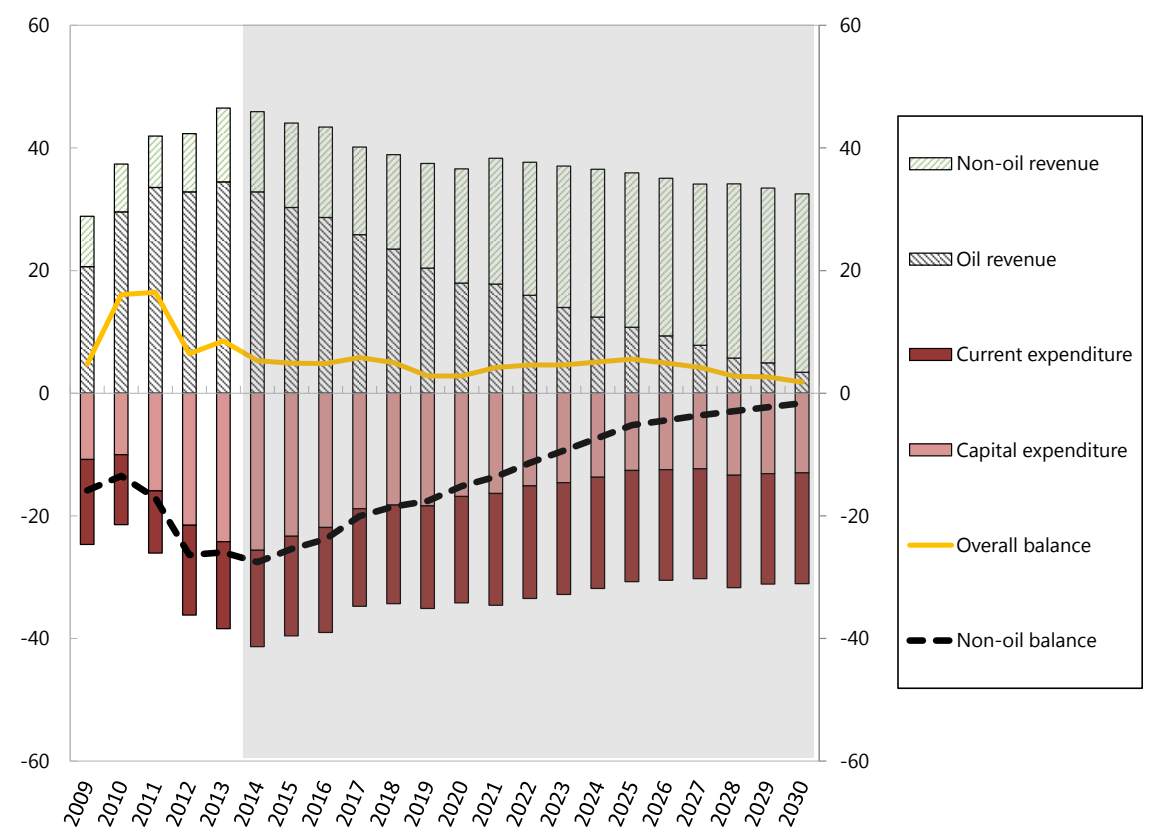

Sources: IMF(2014a); and authors' calculations. Note: All indicators are in percent of total GDP.

\section{Efficiency and absorptive capacity constraints}

The business climate in Congo is among the most challenging in the world. The country ranked 178th out of 189 countries in the 2015 World Bank's Doing Business Survey. The critical factors that influence this ranking are, among others, limited access to electricity, the time and costs involved in cross-border trade and in starting a business, and limited access to financial services. These factors and Congo's relatively low PIMI score (see Dabla-Norris

${ }^{5}$ In our simulations, we consider a cap on public debt of 70 percent of GDP, in line with the current CEMAC's convergence criteria. 
and others (2012)) imply that the capital formation process is subject to absorptive capacity constraints and government inefficiency. Following Pritchett (2000) estimates for sub-Saharan African countries, the maximum absorption capacity parameter is set to 0.5. Furthermore, to capture the idea of rising investment costs and absorptive-capacity constraints, when public investment exceeds by 45 percent of the initial capital investment, investment efficiency or absorptive capacity is assumed to fall until it reaches the lower bound level of 0.2 depending on the magnitude of public investment (see eq. (39)).

Hurlin and Arestoff (2010) and Gupta, Alvar, and Papageorgiou (2011) estimate the depreciation rate of public capital in the range of $2.5-4.3$ percent. Given the low PIMI rank and the limited maintenance spending in developing countries, the annual depreciation rate of public capital is assumed to be 5 percent.

\section{Model Simulations}

Four sets of simulations are considered. In the first set, three scenarios with different public investment paths are examined as below:

- Benchmark scenario. This scenario eliminates the non-oil primary deficit by 2030 . Therefore, public capital spending adjusts at the same pace as oil revenues decline. Public capital investment averages 16 percent of GDP during 2014-2030. Moreover, the debt-to-GDP ratio averages 31 percent and oil revenues decrease from 33 percent in 2014 to around 2.5 percent of GDP in 2030.

- Aggressive investment scenario. This scenario analyzes the implications of a large scale-up of public investment as discussed in IMF(2014a). Public investment peaks at about 35 percent of GDP in 2018 before declining. The path for public investment in this scenario follows the authorities' projected oil-production path.

- Constant investment scenario. In this scenario public investment stays constant until 2020 at a level around 25 percent of GDP, and then declines to the projected path of the baseline scenario. The pace of adjustment is similar to the baseline scenario, but the level reached is higher by 2 percentage points of GDP at the end of the simulation period.

The three above-mentioned scenarios with different paths of public investment anchor the remaining three sets of simulations. These simulations explore the implications of (i) structural reforms that improve public investment efficiency; (ii) oil price and revenue volatility; and (iii) improvements in project selection capacity. 


\section{A. Model Simulations: Investment profiles}

\section{A.1. Baseline scenario}

The baseline scenario delivers the best outcome in terms of debt sustainability and financialassets accumulation in the SWF. As Figure 4 shows, the projected path of public investment delivers a sustainable and sizeable accumulation of public capital. At the same time, given the projected oil revenues, it allows for a sustained increase in savings in the SWF. There is also a mild but sustainable increase in the level of public debt in the long run owing to the government's policy of continuing to finance investments with concessional foreign borrowing. In the long run, this scenario produces higher non-oil GDP and private investment.

Figure 4: Benchmark scenario
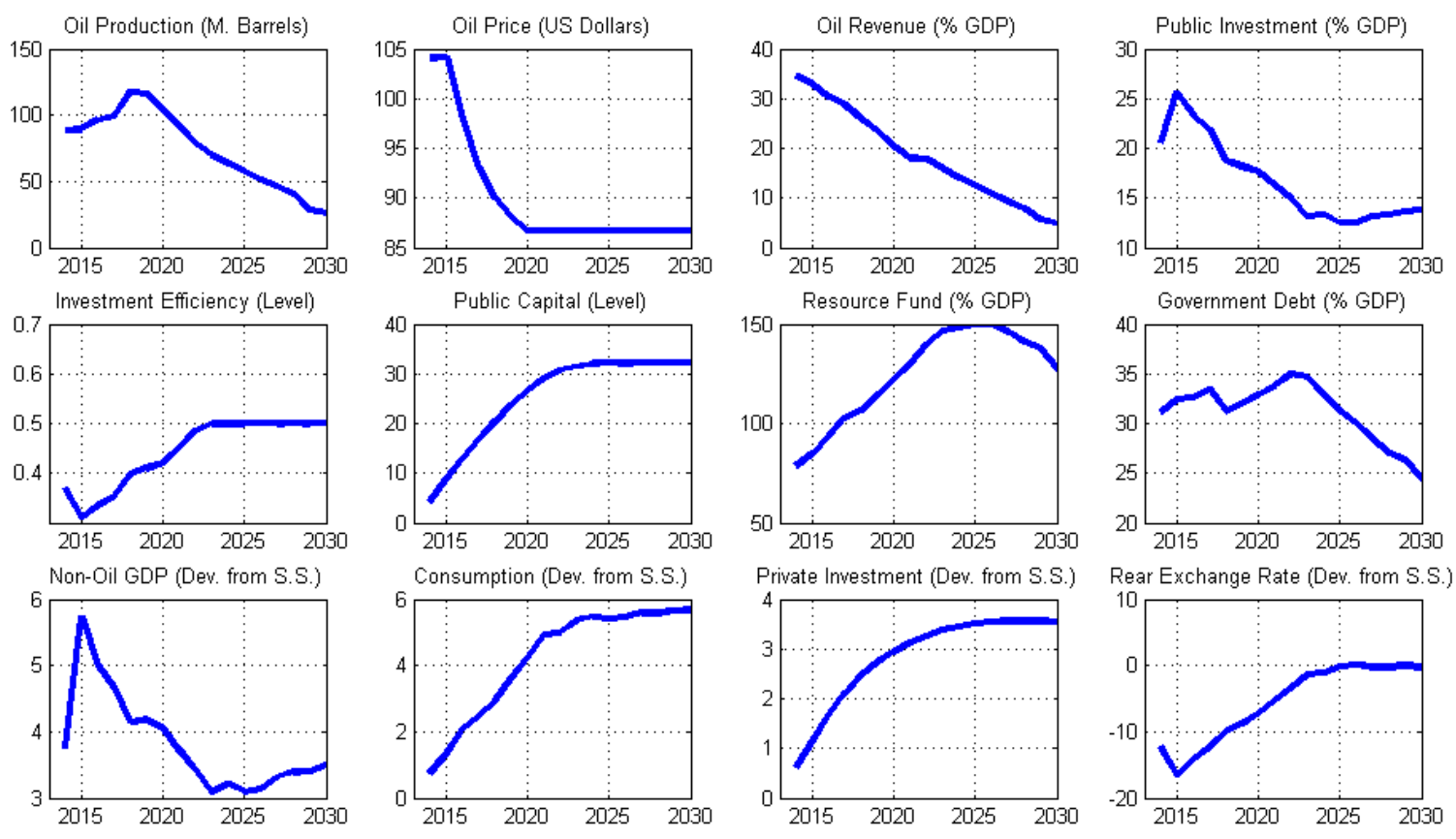

Note: The variables are in percent deviation from a trend-growth path, unless specified otherwise in parentheses. Investment efficiency varies from 0 to 1 (with 0 perfectly inefficient investment and 1 perfectly efficient investment).

The investment efficiency is below the steady state level until 2022. It reaches the minimum level of efficiency in 2015 when public investment peaks at around 26 percent of GDP. Public capital gradually accumulates and stabilizes at the 2024 level, reaching a level of about 32 percent higher than in the steady state. This scaling-up in public investment has positive spillovers to the rest of the economy. The additional public capital financed through external borrowing crowds in non-oil output, private consumption and investment increase. The SWF 
accumulates resources until 2026 when it tops out at around 150 percent of GDP, and then declines to a level of about 125 percent of GDP by 2030.

\section{A.2. Aggressive scenario ("scaled-up")}

The aggressive investment scenario illustrates the dangers of a more pronounced scaling-up of public investment. As Figure 5 shows, the scaling up of public investment to almost 40 percent of GDP lowers the efficiency of investment and results in an unsustainable level of public capital - higher investment initially results in a larger build up of capital stocks but without sufficient investment to cover recurrent costs, public capital begins to depreciate in future periods. The increase in government spending also results in higher non-oil growth during 2014-2030. In the face of declining oil revenues and the large government spending, it is assumed that capital expenditures are financed by first running down the SWF. Once the SWF reaches the minimum level needed to ensure the smooth operation of the pegged exchange rate arrangement (assumed to be 40 percent of GDP) in 2023, the government increases external borrowing to sustain higher government spending than in the baseline. As a result, the debt-toGDP ratio is projected to increase and top 60 percent by 2030.Eventually, the rise in external debt, would force the inevitable downward adjustment in government spending. The longerterm effect of postponing the fiscal consolidation is to erode the SWF and put public debt on an unsustainable path without a beneficial effect in terms of higher non-oil output. 
Figure 5: Aggressive scenario
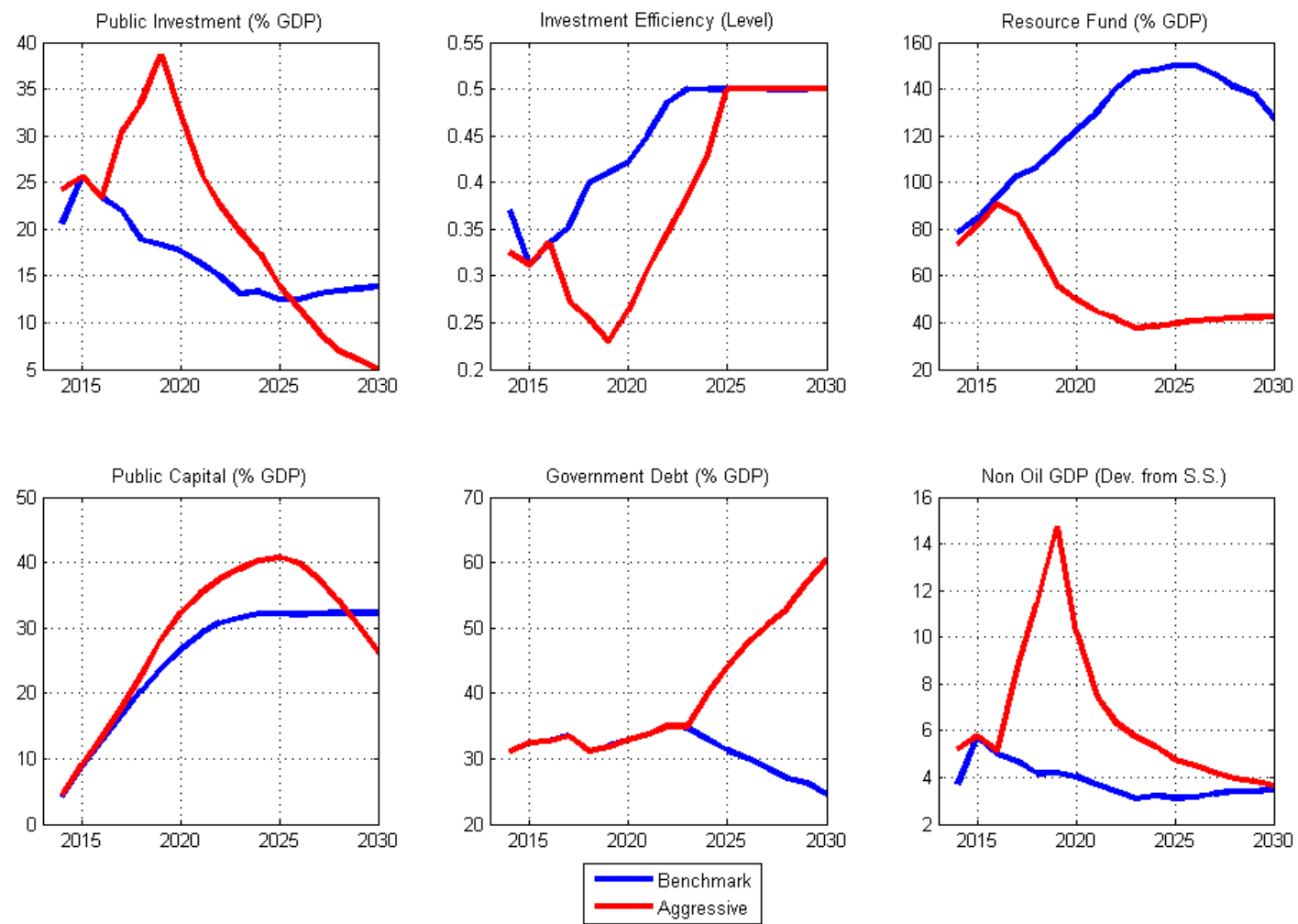

Note: All variables are percentage points, while investment efficiency varies from 0 to 1 (with 0 perfectly inefficient investment and 1 perfectly efficient investment).

\section{A.3. Constant investment scenario}

Maintaining public investment constant until 2020 at around 25 percent of GDP produces a mixed situation. On the one hand, it allows for a higher capital stock and non-oil output than the baseline scenario. On the other hand, this comes with higher risks for debt and fiscal sustainability: unsustainable level of debt and erosion in the SWF (see Figure 6). A pronounced phase of increased public investment puts pressure on the SWF which reaches the lower bound. As a consequence public government debt increases to the maximum threshold which constrains government ability to borrow externally and limits the fiscal space (over 65 percent of GDP). However, in order to sustain the stock of capital and the higher non-oil output, the government needs to invest resources above the benchmark level. At this point, the government faces a policy dilemma: either let public capital to depreciate (i.e., unsustainable capital) and non-oil output to fall compared to the baseline, or adjust the fiscal stance via sizable efforts (e.g., increase taxes). 
Figure 6: Constant scenario
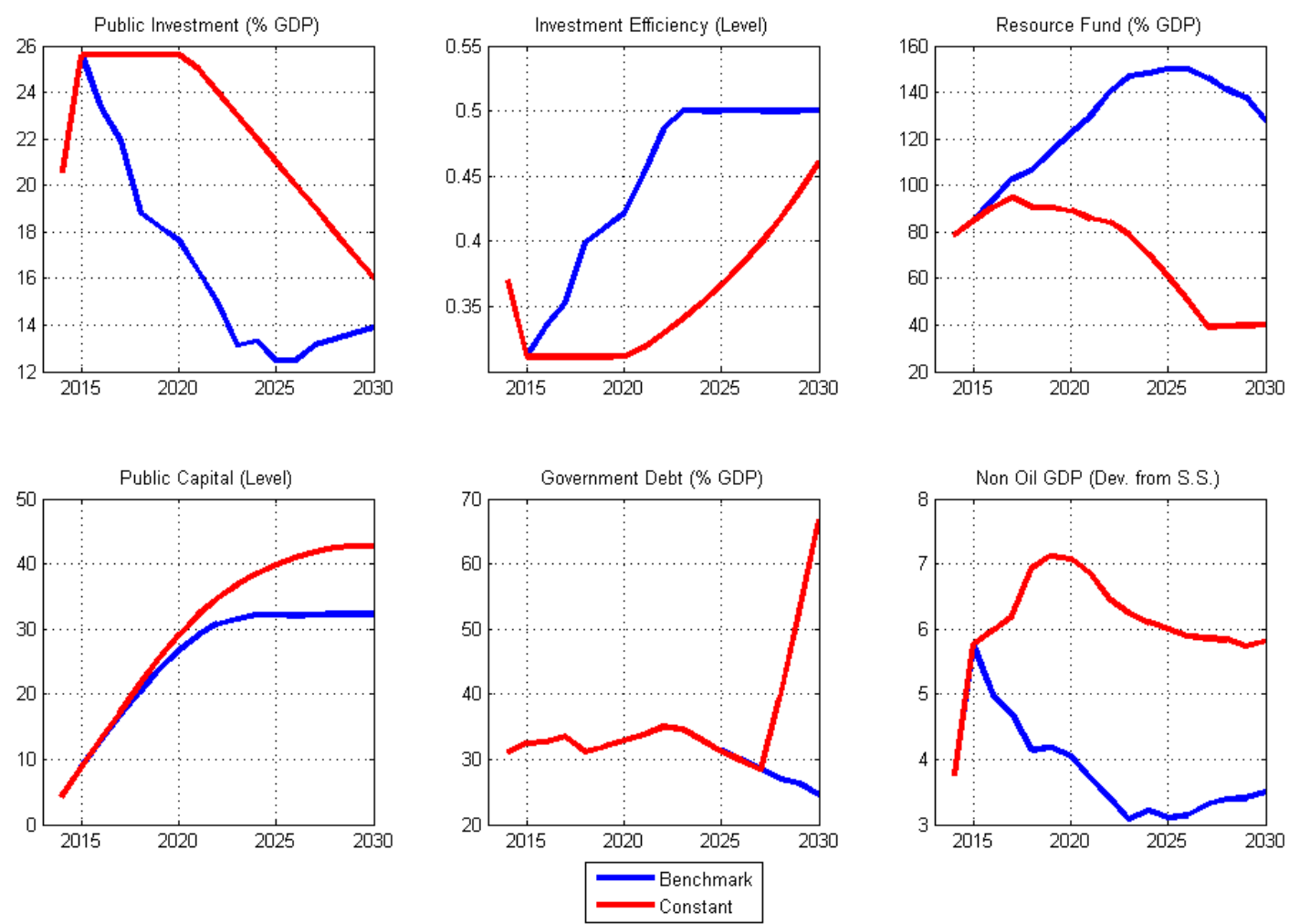

Note: All variables are percentage points, while investment efficiency varies from 0 to 1 (with 0 perfectly inefficient investment and 1 perfectly efficient investment).

\section{B. Model Simulations: Project Implementation Efficiency}

In this section we explore the implications of structural reforms that improve the efficiency of public investment. This is particularly important in developing countries that face a difficult business environment, and absorptive capacity constraints, such as coordination problems, supply bottlenecks, and poor project execution and planning. More broadly, these constraints can refer to institutional policies and/or technical and managerial capacities. First we explore the effects of undertaking structural reforms that improve efficiency in the baseline investment scenario under alternative assumptions on the timing and magnitude of the improvement in efficiency. Second, we analyze the consequences of postponing improvements in investment efficiency in the aggressive scenario.

Panel a. of Figure 7 shows the progressive improvement in efficiency. This captures the fact that strengthening of policy frameworks, including public financial management, takes times to be reflected in better policy outcomes. In this scenario, the maximum absorption capacity 
Figure 7: Benchmark scenario: structural reforms
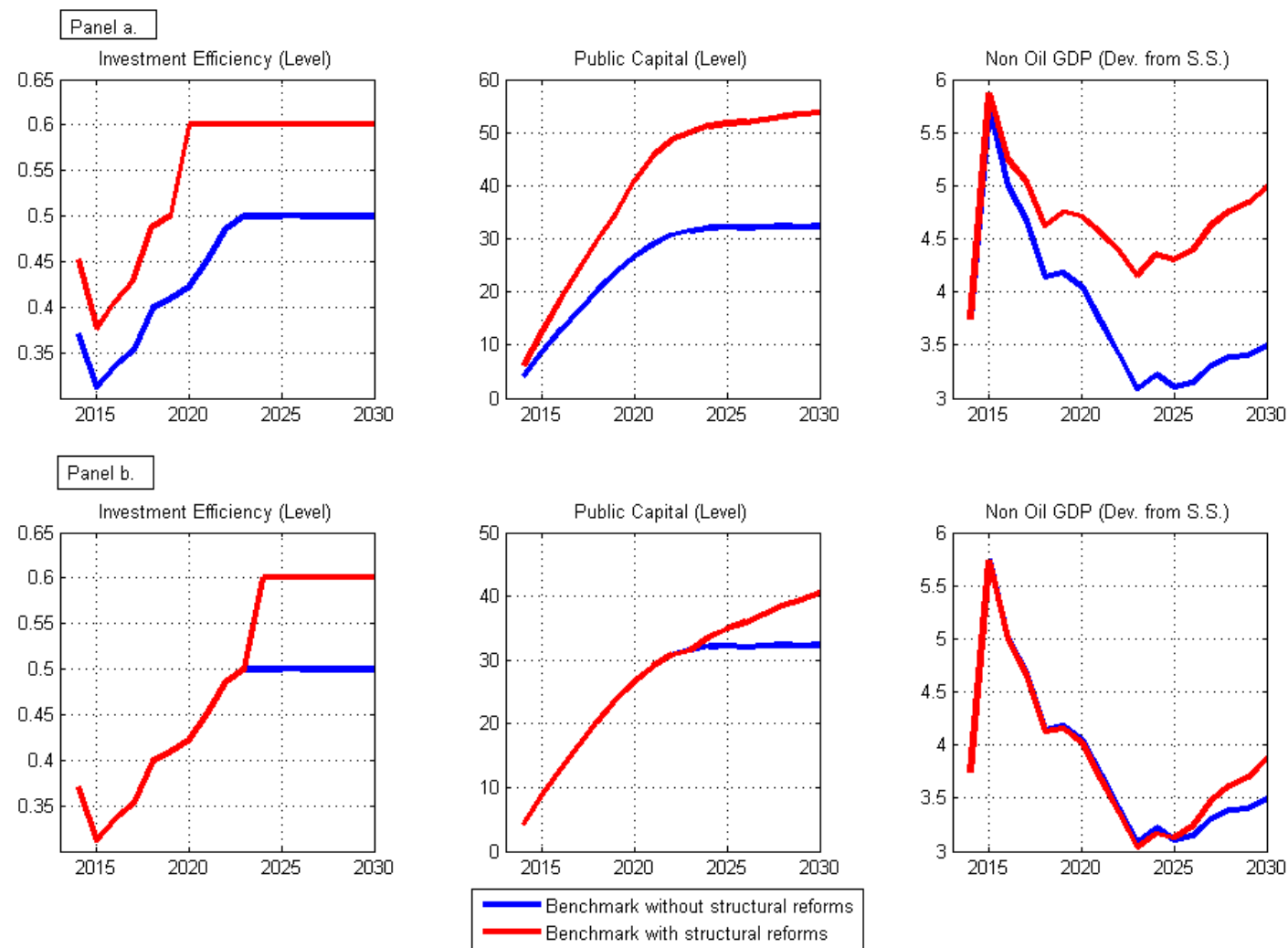

Note: Investment efficiency varies from 0 to 1 (with 0 perfectly inefficient investment and 1 perfectly efficient investment).

(or efficiency) parameter is set to 0.6, consistent with the efficiency level of an emerging market country. This policy produces a sizable and sustainable increase in public capital which has positive spillovers to the rest of the economy, highlighted by higher non-oil growth. Panel b. of Figure 7 depicts the scenario in which structural reforms are delayed by political and economic constraints. The scenario illustrates the missed opportunity to enhance capital and non-oil output growth since most of the investment scaling-up phase precedes the implementation of the structural reforms. By 2030 the public capital stock and non-oil output growth are slightly higher than in the benchmark scenario - the public capital stock is less than 10 percent of GDP above the level reached in the benchmark scenario and non-oil output growth is less than one percentage point above its rate in the benchmark scenario.

As shown in Figure 8 for the aggressive investment scenario, the delayed implementation of structural reforms and the scaling-up of public investment increase the likelihood of an unsustainable level of capital. The latter is avoided only in the case where structural reforms succeed in achieving full investment efficiency, i.e. an efficiency parameter of 1 , which is highly improbable for a developing country. Moreover, the beneficial effects of the structural reforms on non-oil output are limited. A comparison of the scenarios in Figures 7 and 8 shows that the 
benchmark scenario with early implementation of structural reforms yields the best outcome in terms of higher accumulation of the public capital stock and non-oil GDP growth by 2030 .

Figure 8: Aggressive scenario - structural reforms
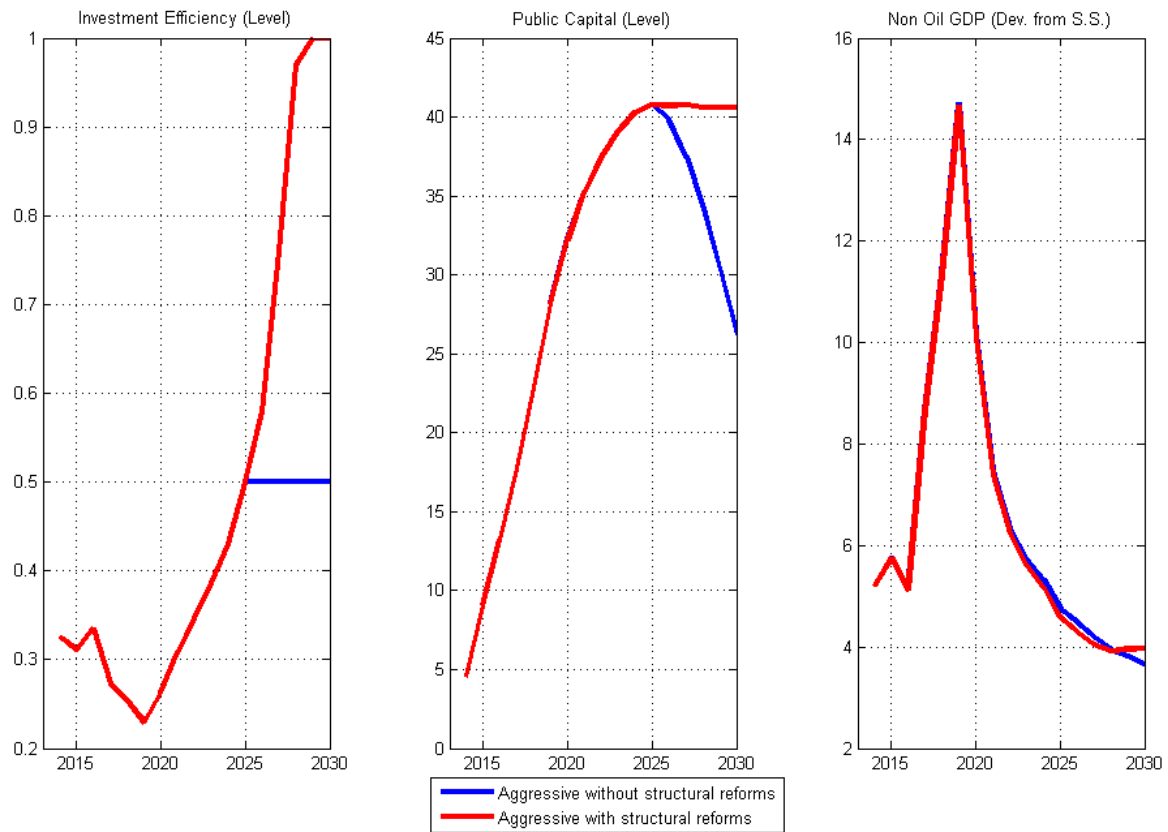

Note: Investment efficiency varies from 0 to 1 (with 0 perfectly inefficient investment and 1 perfectly efficient investment).

\section{Model Simulations: Oil revenue shock}

Using simulated oil price paths over the next 15 years, we generate confidence intervals for the fiscal revenues, SWF, public debt and non-oil output growth for each investment scenario. Oil revenues are computed as the product of the price of oil, oil production, and the government's share of the oil revenue. The baseline oil production path and government share of oil revenue are assumed to be unchanged, and the oil price paths are generated from simulations.

For each simulation we draw a random vector of shocks $\left(\epsilon_{t}^{p o}\right)$ for which we compute oil price vectors. Inflation-adjusted oil prices are assumed to follow a Gaussian random walk as in Hamilton (2009). We re-write equation 31 for the oil price as follows:

$$
\ln \left(P_{t}^{O}\right)=\alpha_{0}+\alpha_{P} \ln \left(P_{t-1}^{O}\right)+\epsilon_{t}^{p o} \text {, where } \epsilon^{p o} \sim i . i . d . \mathcal{N}\left(0, \sigma_{p o}^{2}\right)
$$

\footnotetext{
${ }^{6}$ Using oil price data from 1970 to 2012 , we estimate $\alpha_{P}=0.9753$ and $\alpha_{0}=0.1370$. With a 95 percent probability, over the entire simulation period oil prices are expected to be within the [\$25, $\$ 235]$ interval.
} 
Figure 9: Benchmark scenario: Oil Shocks (confidence intervals)
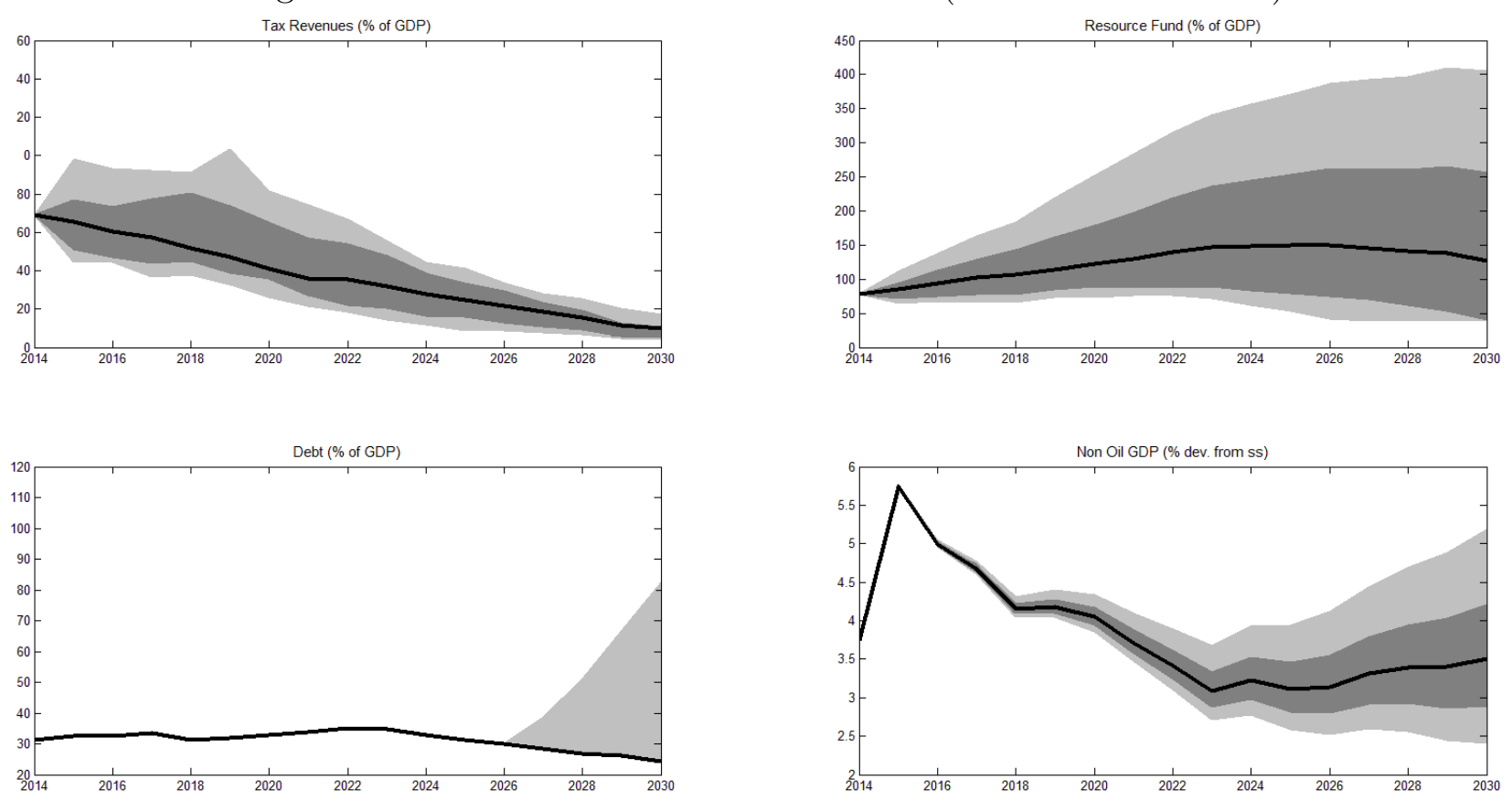

Note: Confidence bands are based on 500 simulations. Solid lines refer to the median paths. Light gray areas represent one-standard deviation confidence intervals, while dark gray areas refer to two-standard deviation confidence intervals.

Oil price volatility increases over time. This effect dominates the overall uncertainty regarding oil revenues. As in the benchmark case, the median size of the resource fund reaches a maximum at around 150 percent of GDP in 2026, while at the end of the simulation period the resource fund is about 120 percent of GDP. Two-standard deviations confidence intervals show that the SWF builds up to 400 percent of GDP when oil prices are high. However, when oil prices are at the lower bound, the SWF reaches the minimum imposed threshold of 40 percent of GDP. In this case, public debt builds up to unsustainable levels and can eventually exceed the CEMAC convergence criterion, which now stands at 70 percent of GDP. These results emphasize fiscal revenue risks stemming from oil price volatility that can endanger debt sustainability. In terms of non-oil output growth the median results show an average growth of around 3.5 percentage points. Confidence intervals for growth show relative fluctuations from the baseline level in the order of \pm 2 percentage points. High oil prices allow higher government revenues to finance higher government spending and boost non-oil growth. By contrast, low oil prices lead oil revenues to deplete more rapidly. As a result, government spending needs to be financed by drawing down the resource fund and then by a build up of debt. The lower oil revenues constrain government spending and non-oil output. Also, the higher government borrowing crowds out private sector investment and lowers growth potential.

Figures 11 and 12 (Appendix) show that aggressive and constant scenarios yield similar 
findings. In these scenarios, the slower pace of fiscal adjustment in the face of lower oil prices and declining oil revenues results in a quicker draw-down of savings, larger build up in debt and lower non-oil growth thereby emphasizing the vulnerability to an adverse oil shock from slow fiscal adjustment.

\section{Model Simulations: Project selection}

In this section we explore the implications of improvements in project selection capacity for the build up of capital and the spillovers to the real economy. $]^{7}$ We assume that the government can allocate its resources between two types of projects which have a different influence on the economy. The government decides how much to invest in high productivity projects $\tilde{g}_{t}^{I H}$ and low productivity projects $\tilde{g}_{t}^{I L}$ :

$$
\begin{aligned}
\tilde{g}_{t}^{I H} & =\varsigma \tilde{g}_{t}^{I} \\
\tilde{g}_{t}^{I L} & =(1-\varsigma) \tilde{g}_{t}^{I}
\end{aligned}
$$

where $\varsigma$ represents the share of total government investment in projects with high productivity. The capital stocks in the high productivity projects $k_{t}^{G H}$ and in the low productivity projects $k_{t}^{G L}$ are assumed to evolve according to:

$$
\begin{aligned}
k_{t}^{G H} & =\left(1-\delta^{G H}\right) k_{t-1}^{G H}+\tilde{g}_{t}^{I H} \\
k_{t}^{G L} & =\left(1-\delta^{G L}\right) k_{t-1}^{G L}+\tilde{g}_{t}^{I L}
\end{aligned}
$$

Furthermore we assume that $\delta^{G H}<\delta^{G L}$ to capture the lower obsolescence of higher quality project. Accordingly, total public capital is given by:

$$
k_{t}^{G}=k_{t}^{G H}+k_{t}^{G L}
$$

As in the baseline case, public capital is productive. However, in this case, the elasticity of public capital is not fixed but varies according to the amount of investment in a specific project.

$$
y_{t}^{j}=z^{j}\left(k_{t-1}^{j}\right)^{1-\alpha^{j}}\left(L_{t}^{j}\right)^{\alpha^{j}}\left(k_{t}^{G}\right)^{\alpha^{G H}\left(\varsigma-\left(\frac{\alpha^{G L}}{\alpha^{G H}}\right)(1-\varsigma)\right)}
$$

In this setup, a shift in investment towards lower productivity projects impacts negatively the elasticity of public capital with respect to output. By varying $\varsigma$ between 0 and 1, we obtain the full spectrum of public investment allocation.

\footnotetext{
${ }^{7}$ However, as discussed in IMF $(2015)$, the quality of public investment management involves not only project selection but also implementation and planning.
} 
Figure 10: Project selection: public capital and non-oil GDP growth
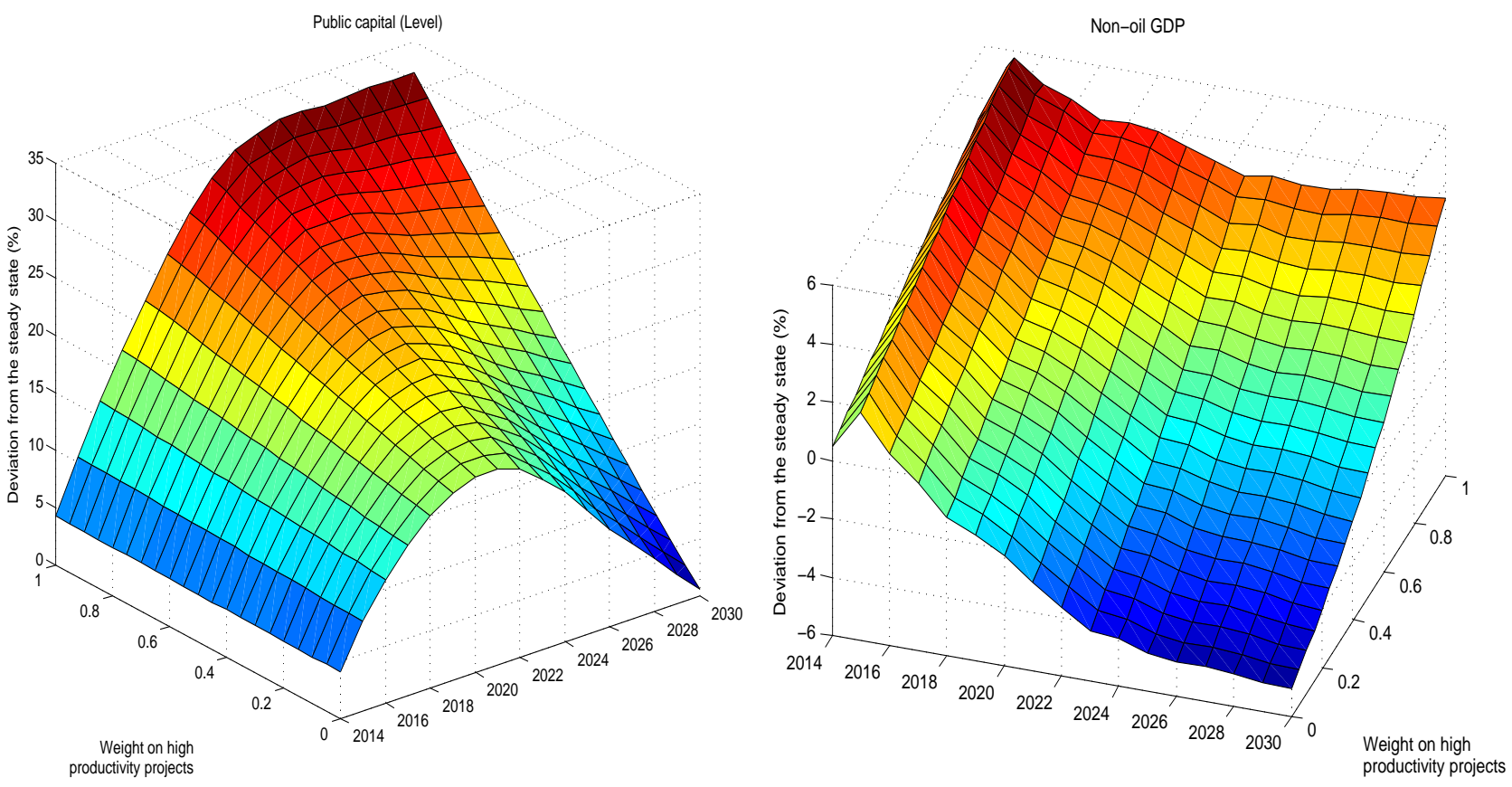

Note: The benchmark case $(\varsigma=1)$ represents the case in which the entire capital investment is allocated to the high productivity and low depreciation project. The case when $\varsigma=0$ is associated with the entire capital spending allocated to the low productivity and high depreciation project.

As depicted in Figure 10, misallocation of resources towards low productivity projects will result in lower capital stock and output growth. According to our simulations, when more than $1 / 3$ of investment is tilted towards "white elephant" projects, output growth enters into the negative territory. These results highlight the risks of resource misallocation during the project selection process. 


\section{Conclusions}

This paper illustrates the policy tradeoffs faced by a highly oil-dependent country that has large social and infrastructure gaps, faces absorptive and implementation capacity constraints, and is near the peak of its oil production. The model simulations underscore the importance of fiscal consolidation to preserve macroeconomic stability in the medium- to long-run when oil reserves are exhausted. The paper shows that aggressively scaling up investment could lead to a rapid accumulation of public capital and higher non-oil growth and emphasizes the importance of fiscal adjustment in the case of oil price declines. However, as more oil revenues are devoted to public investment less can be saved, leaving the country vulnerable to future negative oil price shocks. As oil revenues decline, public investment would increasingly need to be financed by a draw down of the saving fund. Public investment can also be financed by borrowing from either domestic or foreign sources. A rapid scaling up of investment could, therefore, initially result in a draw-down of the saving fund in the face of declining oil revenues. Once savings hit a minimum acceptable lower bound - in this case the level of reserves needed to ensure continued smooth operation of the pegged exchange rate arrangement - the government can choose to borrow to close the fiscal gap. However, there is a limit to the level of debt market participants will be willing to provide. Therefore, eventually, once the relevant threshold for public debt is reached, a downward adjustment of government spending would become inevitable. The model simulations assume that the country authorities draw on their resource fund before accumulating further debt. In practice, country authorities may choose to borrow and preserve their gross savings or may engage in a combination of the two. In all cases, the longer-term effect of postponing the fiscal consolidation is to run up unsustainable public debt and leave no financial assets to provide a permanent income once oil reserves are exhausted.

The paper also explores an intermediate option where public investment is maintained constant for a period of time before fiscal consolidation kicks in. Naturally, this option leads to a lower build up of savings in the long run and a higher build up of debt than the baseline fiscal consolidation scenario, and increases the vulnerability of the economy to negative oil price shocks.

Our results highlight the sensitivity of budgetary revenues to oil price shocks, which could affect both government spending and potential non-oil output growth and which emphasize the importance of fiscal adjustment in the case of oil price declines. Moreover, our simulations emphasize the positive impact of improving public investment efficiency, which can contribute to a sustainable and higher-level of public capital without adversely affecting fiscal sustainability. This is particularly important for a country like Congo where public investment efficiency is lower than the average for Low Income Developing Countries (see IMF(2015)). Finally, we explore the consequences of investment project misallocation and show their negative effects on output growth and public capital. 


\section{References}

Berg, Andrew, Rafael Portillo, Shu-Chun S. Yang, and LuisFelipe Zanna, 2013, "Public Investment in Resource Abundant Developing Countries," IMF Economic Review, Vol. 61, No. 1, pp. $92-129$.

Buffie, Edward F., Andrew Berg, Catherine Patillo, Rafael Portillo, and Luis-Felipe Zanna, 2012, "Public Investment, Growth and Debt Sustainability: Putting together the Pieces," IMF WP/12/17\%.

Collier, Paul, Frederick van der Ploeg, Michael Spence, and Anthony J. Venables, 2010, "Managing resource revenues in developing countries," IMF Staff Papers, 57 (1).

Dabla-Norris, Era, Jim Brumby, Annette Kyobe, Zac Mills, and Chris Papageorgiou, 2012, "Investing in Public Investment: An Index of Public Investment Efficiency," Journal of Economic Growth, Vol. 17, pp. 235-266.

Ghilardi, Matteo, and Sergio Sola, 2015, "Investment Scaling-up and the Role of Government: the Case of Benin," IMF WP/15/69.

Gupta, Sanjeev, Kangur Alvar, and Chris Papageorgiou, 2011, "Efficiency-Adjusted Public Capital and Growth," IMF Working Paper WP/11/21\%.

Hamilton, James D, 2009, "Understanding Crude Oil Prices," Energy Journal, Vol. 30, No. 2, pp. 179-206.

Hurlin, Christophe, and Florence Arestoff, 2010, "Are Public Investment Efficient in Creating Capital Stocks in Developing Countries?" Economics Bulletin, Vol. 30, No. 4, pp. 3177-3187.

International Monetary Fund, 2012, Macroeconomic Policy Frameworks for Resource-Rich Developing Countries (Washington D.C.).

- , 2014a, Republic of Congo - 2014 Article IV Consultation - Staff Report (Washington D.C.: IMF Country Report 14/272).

—, 2014b, World Economic Outlook (Washington D.C.).

—, 2015, Making Public Investment More Efficient (Washington D.C.).

Krugman, Paul, 1987, "The Narrow Moving Band, the Dutch Disease, and the Competitive Consequences of Mrs. Thatcher: Notes on Trade in the Presence of Dynamic Scale Economies," Journal of Development Economics, Vol. 27, No. 1-2, pp. 41-55.

Matsuyama, K., 1992, "Agricultural Productivity, Comparative Advantage and Economic Growth," Journal of Economic Theory, Vol. 58, No. 2, pp. 317-334. 
Melina, Giovanni, Shu-Chun S. Yang, and Luis-Felipe Zanna, 2014, "Debt Sustainability, Investment and Natural Resource in Developing Countries: The DIGNAR model," IMF WP/14/50.

Pritchett, Lant, 2000, "The Tyranny of Concepts: CUDIE (Cumulated, Depreciated, Investment Effort) Is Not Capital," Journal of Economic Growth, Vol. 5, No. 4, pp. 361-384.

Sachs, Jeffrey D., and Anders M. Warner, 1997, Leading Issues in Economic Development, chap. Natural Resource Abundance and Economic Growth (Oxford).

— , 2001, "The Curse of Natural Resources," European Economic Review, Vol. 45, pp. $827-838$.

van der Ploeg, Frederick, 2011, "Natural Resources: Curse or Blessing?" Journal of Economic Literature, Vol. 49, No. 2, pp. 366-420.

van der Ploeg, Frederick, 2012, "Bottlenecks in Ramping Up Public investment," Int Tax Public Finance, Vol. 19, pp. 509-538.

van der Ploeg, Frederick, and S. Poelhekke, 2010, "Volatility and the Natural Resource Curse," Oxford Economic Papers. 


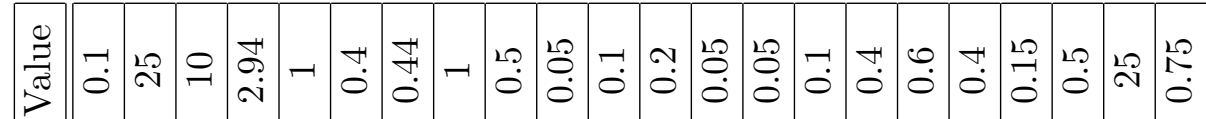

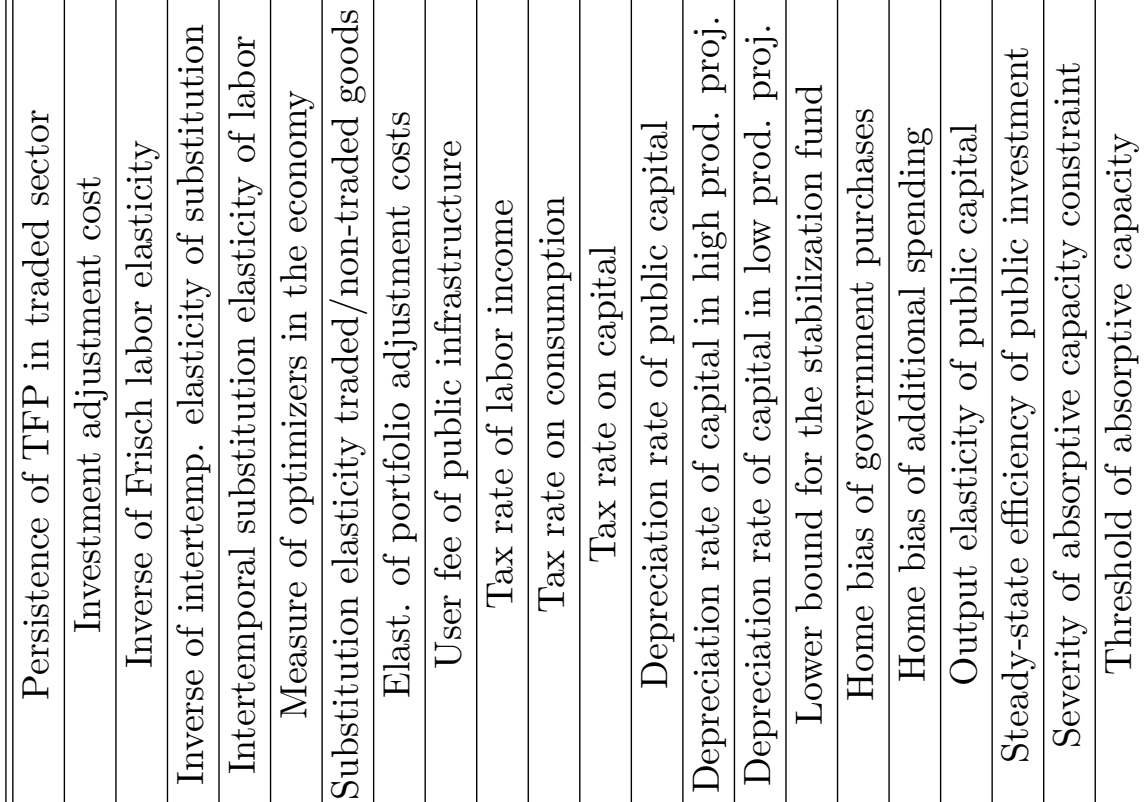

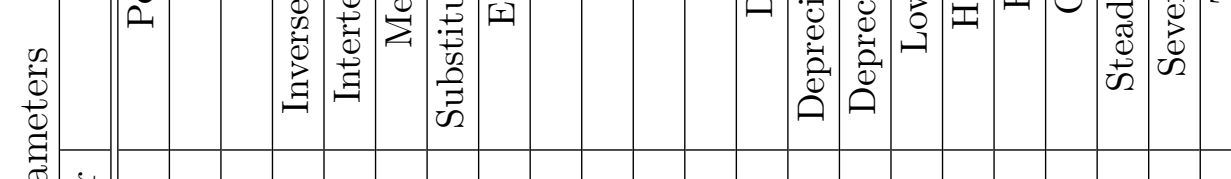

:

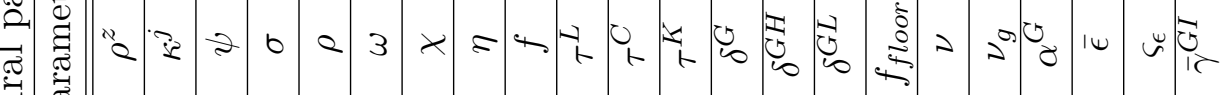

$\Xi$

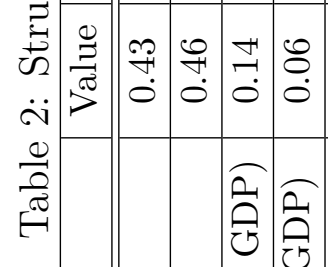

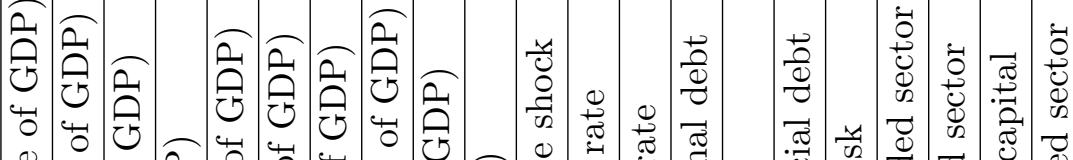

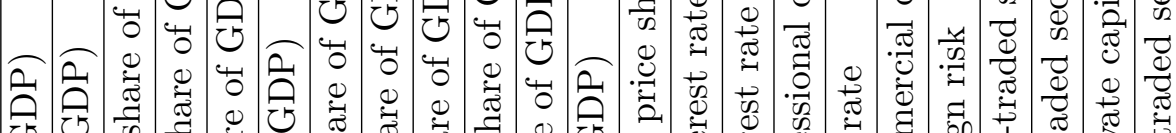

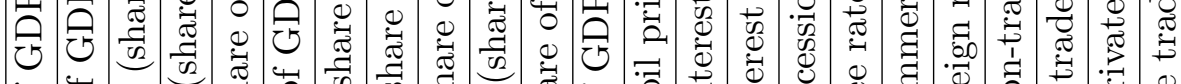

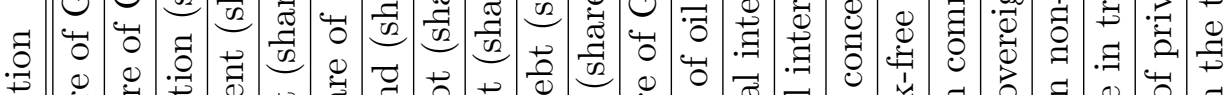

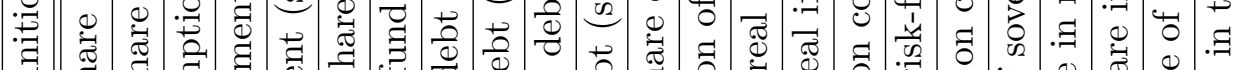

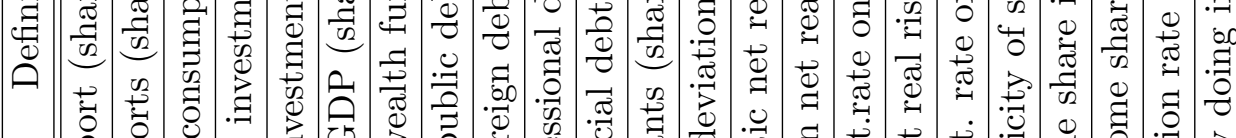

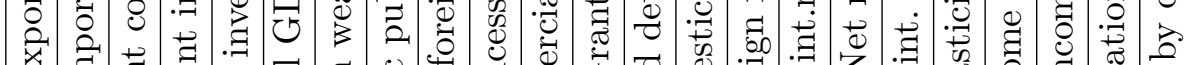

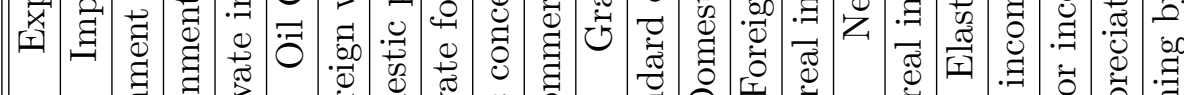

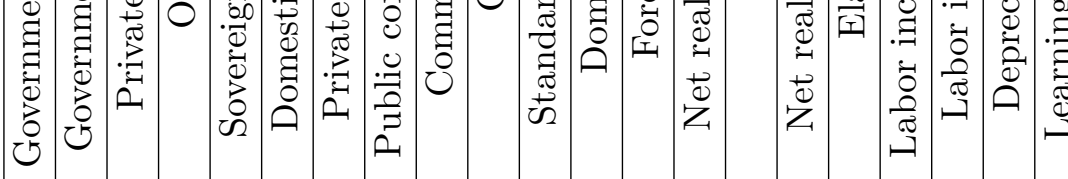




\section{Graphs}

Figure 11: Aggressive scenario: oil shocks (confidence intervals)
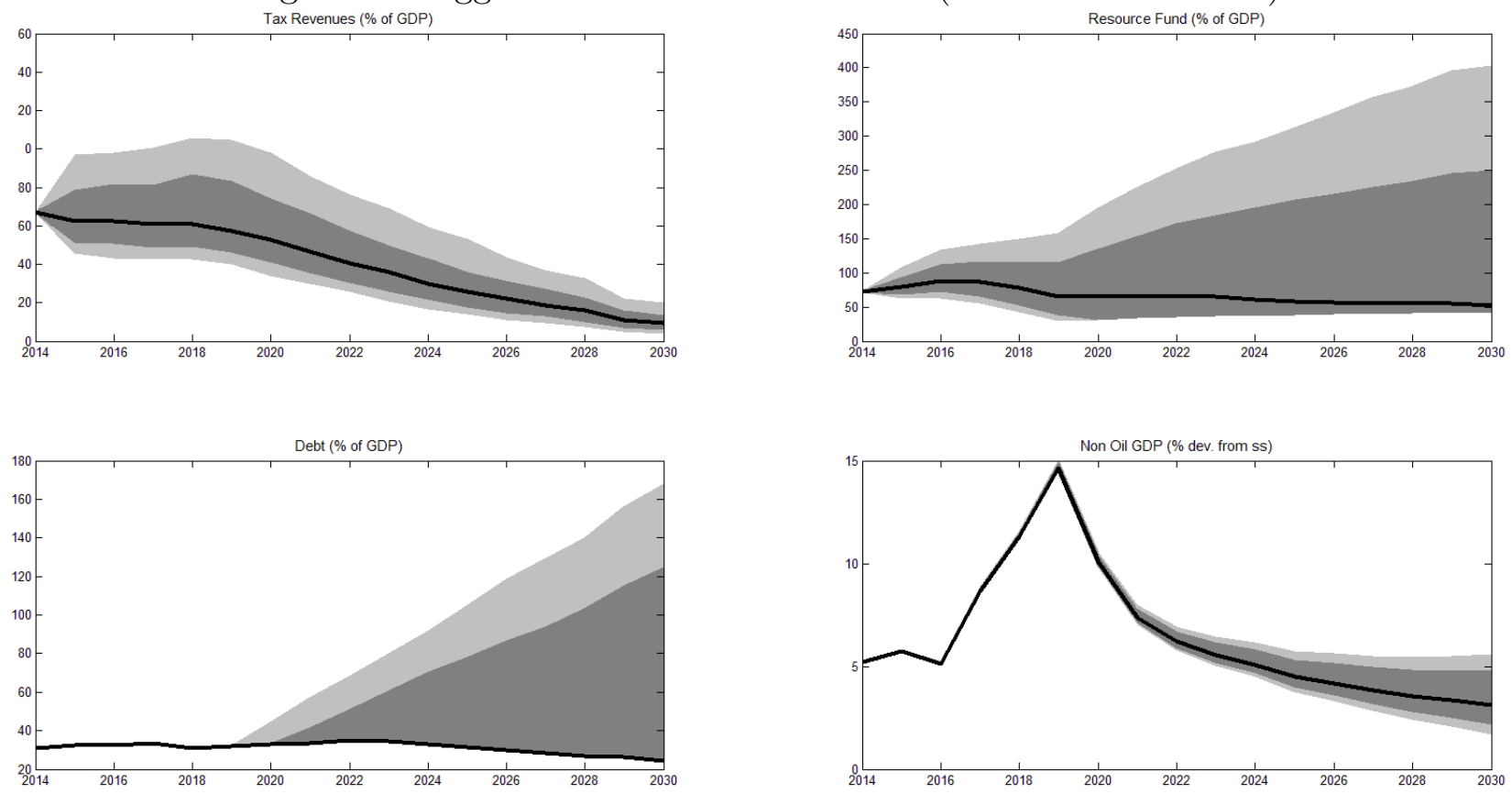

Note: Confidence bands are based on 500 simulations. Solid lines refer to the median paths. Light gray areas represent one-standard deviation confidence intervals, while dark gray areas refer to two-standard deviation confidence intervals. 
Figure 12: Constant scenario: oil shocks (confidence intervals)
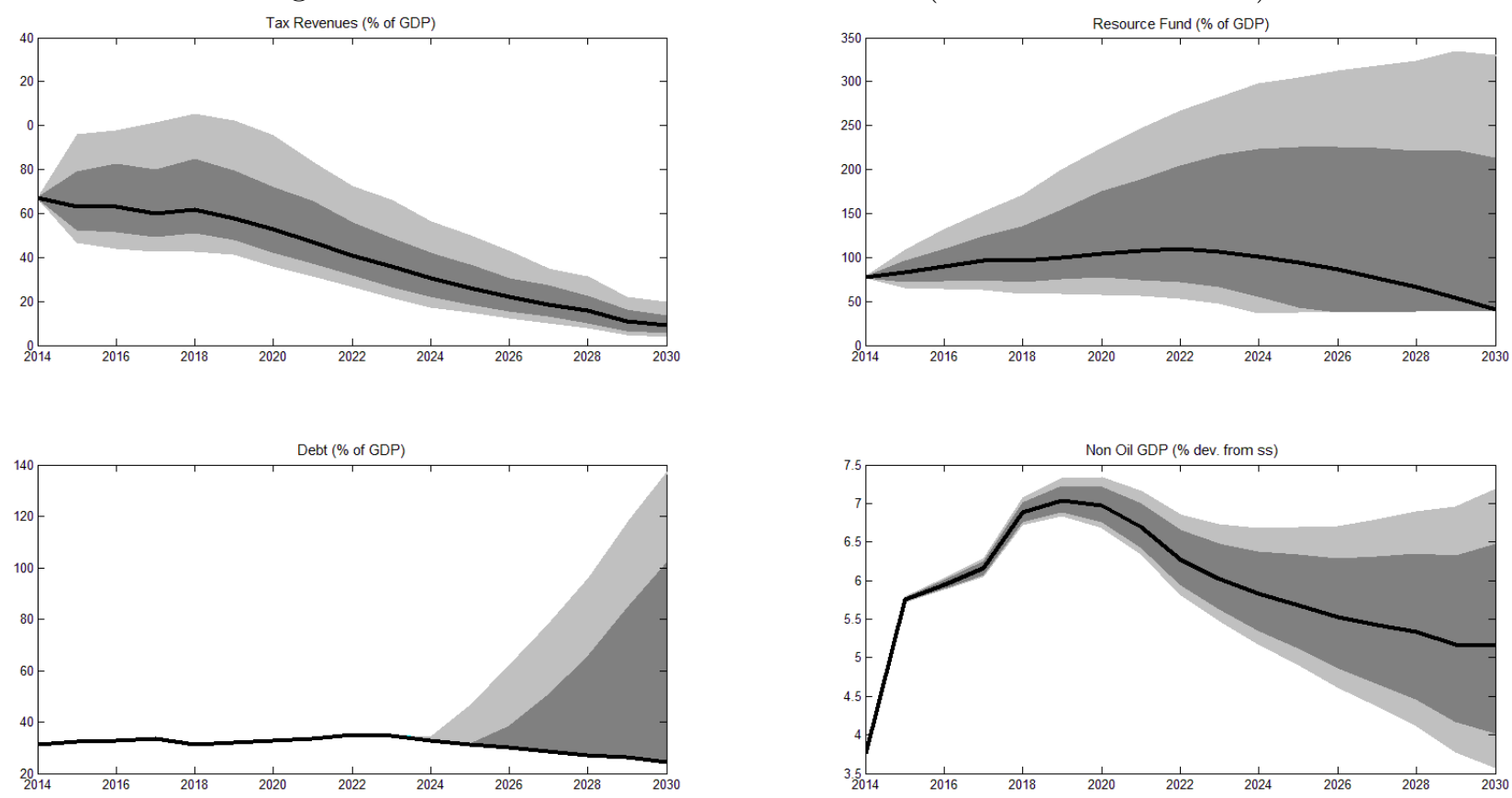

Note: Confidence bands are based on 500 simulations. Solid lines refer to the median paths. Light gray areas represent one-standard deviation confidence intervals, while dark gray areas refer to two-standard deviation confidence intervals. 